\title{
Deliberative inclusion of minorities: patterns of reciprocity among linguistic groups in Switzerland
}

\author{
SERAINA PEDRINI ${ }^{1,2}$ *, ANDRÉ BÄCHTIGER ${ }^{3}$ AND \\ MARCOR. STEENBERGEN ${ }^{4}$ \\ ${ }^{1} \mathrm{PhD}$ Student, Institute of Political Science, University of Bern, Bern, Switzerland \\ ${ }^{2}$ Research Assistant, Department of Political Science, University of Zurich, Zurich, Switzerland \\ ${ }^{3}$ Swiss National Science Foundation Research Professor, Institute for Political Science, University of Lucerne, \\ Switzerland \\ ${ }^{4}$ Professor, Department of Political Science, University of Zurich, Zurich, Switzerland
}

\begin{abstract}
We present a model of deliberative inclusion, focusing on reciprocity in the interaction between structural minorities/disadvantaged groups and majorities/privileged groups. Our model, however, comes with a 'friendly amendment': we have put the 'burden of reciprocity' mainly on majorities and privileged groups. It is mainly their obligation to seriously listen and respond to the demands and arguments of minorities and disadvantaged groups and show a willingness to respect and accommodate these interests. Empirically, we apply our model to the interaction of linguistic groups in the Swiss parliament. We find a highly egalitarian, sometimes even minority-favoring mode of interaction between the German-speaking majority and linguistic minorities. The German-speaking majority seems to be willing to take the 'burden of reciprocity' when linguistic minorities' vital interests are concerned. Conversely, linguistic minorities are slightly more self-referential and adversarial under such conditions.
\end{abstract}

Keywords: deliberation; minorities; inclusion

\section{Introduction}

The inclusion of structural minorities and disadvantaged groups looms large in the study of democracy. The standard majoritarian model of democracy is widely understood to be frequently unable to safeguard vital interests of structural minorities and disadvantaged groups. Therefore, several institutional devices have been proposed in order to include and advance the interests of minorities and disadvantaged groups. In the past decade, however, the study of inclusion has increasingly taken a deliberative turn (Williams, 1998; Urbinati, 2000; Valadez, 2001; Dryzek and Niemeyer, 2008). Rather than focusing on formal and institutional means of inclusion (such as proportional representation, a minority veto, or re-districting), many deliberative approaches take an informal and dynamic view of inclusion

* E-mail: pedrini@ipz.uzh.ch 
(see O'Flynn, 2010). Both mainstream and Habermasian-inspired versions of deliberation entail the idea of equal participation and symmetric dialogue, reasoned argument, common-good orientation, serious and respectful listening (and responding) to other participants' claims, and mutual agreement based on the 'forceless force of the better argument'. These ideas spark hope for promoting the interests of structural minorities and disadvantaged groups.

Despite interest in deliberative approaches in recent years, the exact specification and empirical translation of deliberative ideals in the context of minority inclusion has lagged. This lag may not be so surprising, given that deliberative approaches are far from fool-proof devices for inclusion. The problem is that mainstream and Habermasian-inspired forms of deliberation might actually hamper inclusionary goals. For instance, why should disadvantaged groups respectfully listen to privileged groups or even transcend their interests in the light of the 'better' argument, especially if they have experienced inequality or if their vital interests are at stake? As Williams (1998) has noted, requiring the selflessness and self-transformation of the disadvantaged is deeply unfair. This is a valid objection that is not easily addressed by the mainstream deliberative approach. Therefore, we propose a deliberative approach with 'friendly amendments'. Our approach focuses on one crucial principle of deliberation - reciprocity - but with a twist. Reciprocity means that discourse participants should listen and respond to each other and do so respectfully. However, the trick is to place the 'burden of reciprocity' primarily on majorities and privileged groups; it is mainly their obligation to seriously listen and respond to the demands and arguments of the disadvantaged and show a willingness to respect and accommodate these interests. Conversely, structural minorities and disadvantaged groups are not held fully accountable to these standards. They may be deliberative, but may also adopt a more adversarial stance toward majorities and privileged groups. This relaxation, however, is conditional and partial. On the one hand, the less inequality structural minorities and disadvantaged groups have experienced and the less their vital interests are at stake, the more we expect them to converge to majority standards. On the other hand, minorities are also expected to make 'just' demands that do not compromize the basic well-being of majorities.

As with defining proper standards of deliberative inclusion, there has also been little empirical and systematic examination of inclusion in the context of structural minorities and disadvantaged groups. In this study, we make a first step in this direction and investigate patterns of reciprocity in the context of linguistic minorities in Switzerland (French, Italian and Romansh speakers). ${ }^{1}$ To be sure, linguistic groups in Switzerland do not directly qualify as 'disadvantaged' groups (such as African Americans in the United States), since they have not experienced

\footnotetext{
${ }^{1}$ In 2000, the Swiss population (foreigners not included) consisted of $72.5 \%$ Swiss-German citizens, $21 \%$ French-speaking citizens, 4.3\% Italian speaking and 0.6\% Romansh-speaking citizens (Eidgenössische Volkszählung, 2000).
} 
deep inequality or oppression. However, they form structural minorities, and when their vital interests are at stake, they have no formal veto power to prevent unwanted legislation but are largely dependent on the decisions of the Germanspeaking majority to realize their interests. Moreover, there have been recurrent complaints of marginalization of linguistic minorities by German speakers. As such, an empirical investigation of deliberative inclusion of linguistic minorities in Switzerland is far from misdirected. At the same time, the institutional architecture of the Swiss political system is also conducive to deliberative forms of policy-making: it is a consensus system with non-parliamentary features, enabling political actors to engage in deliberation. Moreover, the party system is not organized along linguistic cleavages, reducing partisan incentives to politicize linguistic conflicts. This is combined with a specific motivation among the Germanspeaking majority to be receptive to demands from linguistic minorities (Bächtiger and Steiner, 2004). Thus, favorable institutional conditions and appropriate actor motivations should provide fertile ground for our conception of deliberative inclusion. Put differently, the Swiss case enables us to explore how well the ideal of reciprocity is realized in practice when conditions are fairly ideal. Of course, future research will need to engage in comparative analysis, but the goal of this article is to delineate a starting point for empirical analysis and to test a novel set of methodological tools to capture patterns of reciprocity in real world decision cases.

We focus on two Swiss parliamentary decisions that deal with linguistic issues and directly concern linguistic minorities' vital interests, namely the language article and the language bill; in addition, we focus on a contrasting decision, the labor law revision, which does not touch upon vital interests of the linguistic minorities. For the three cases, we explore patterns of reciprocity in the committee and plenary debates of the first and second chambers of parliament. We analyze how often linguistic minorities are referred to, how often linguistic minorities refer to other actors, and whether this is done in a respectful or disrespectful way. Further, we perform an in-depth analysis of reciprocity and explore how often the arguments of linguistic minorities are referred to by the German-speaking majority and whether this is done in a respectful (or disrespectful) way. Our empirical analysis of deliberative inclusion draws on Steven Levitt's (2004) analysis of discrimination in the United States. We calculate frequencies for reciprocity rates as a function of the speaker's status - linguistic minority or linguistic majority - controlling for other characteristics of the speaker (such as gender, role, or partisan affiliation), as well as characteristics of the context (different issues or first vs. second chamber). While a major focus of our article is to determine the extent of deliberative inclusion of linguistic minorities in parliamentary debates, we also attempt to shed some light on potential intervening contextual factors, namely public vs. non-public arenas, and issues touching upon vital interests of linguistic minorities vs. other issues.

The remainder of the paper is organized as follows. The second section presents our model of deliberative inclusion. The third section provides background on deliberative inclusion in the context of linguistic groups in Switzerland, identifies 
some contexts of deliberative inclusion, discusses the methodological approach, and presents the empirical results. The fourth section concludes.

\section{Models of minority inclusion: from the 'politics of presence' to deliberative politics (with 'friendly amendments')}

How can the interests of structural minorities and disadvantaged groups be equally included in processes of political decision making? This is a crucial question for democratic theory, since structural minorities and disadvantaged groups cannot hope to become majorities or advantaged groups in the near or even distant future (such as electorally produced minorities who can hope to be turned into majorities in the next legislative period). Rather, their cultural and economic flourishing is dependent on the actions of majorities and privileged groups. Classic roads to minority inclusion are representational and institutional. Philips (1995), for instance, has called for a 'politics of presence', which means that members of disadvantaged groups are physically present in the institutions of liberal democracy (such as parliaments). Such presence is needed because only members of these groups have the capacity to give an authentic voice to the exclusions and oppressions they have experienced. Besides, scholars have also identified several institutional devices that can further the inclusion and representation of disadvantaged groups and minorities. For instance, Proportional Representation electoral systems or re-districting can increase the chances that disadvantaged groups are better represented (see, e.g. Amy, 1997).

In recent years, however, models of inclusion have increasingly taken a deliberative turn. The promise of deliberation lies in the idea of the free and fair exchange of arguments leading to more consensual, common-good oriented, and inclusive policy outcomes. Deliberation also takes an in-depth look at the process of policy-making, a problem generally ignored by institutional approaches to minority inclusion. This addresses the long-standing problematique that institutions do not determine behavior, but only structure it. Put differently, institutional arrangements may provide minority actors with formal means of inclusion - Young (2002) calls this 'external' inclusion, but this may not (always) translate into what Young calls 'internal' inclusion, that is, that minority demands may not be listened to and are not taken up by majorities. A deliberative approach may help to fill this gap.

There is, however, a dearth of models specifying what deliberation among minority and majority groups exactly means. Among the few attempts to develop a deliberative model of inclusion is Williams' model of legislative decision making where 'participants aim at mutual agreement arrived at through a process of rational argumentation' (Williams, 1998: 138). This model conforms to a classic, Habermasian-inspired conception of deliberation. According to this view - which Bächtiger et al. (2010a label type I deliberation, deliberation is a systematic process of reason-giving and reason-taking, which aims to achieve consensus via the 'forceless force of the better argument'. Urbinati (2000: 776), in turn, proposes a model of 
deliberative 'advocacy': 'A good representative democracy needs [...] deliberators who judge and in turn plead causes 'passionately' in accordance with the principles and procedures of democratic government'. This model conforms to an expanded program of deliberation. According to this view - which Bächtiger et al. (2010a label type II deliberation, deliberation is stripped of its rationalistic bias, and made compatible with passion, emotion, and the expression of self-interest.

Type II deliberative democrats have also forcefully argued that rationalist forms of deliberation can exclude disadvantaged groups. According to Sanders (1997: 349), 'deliberation requires not only equality in resources and the guarantee of equal opportunity to articulate persuasive arguments but also equality in "epistemological authority", in the capacity to evoke acknowledgement of one's arguments'. In this regard, Young (2001) argues that when people share convictions, values, affective orientations, and cultural background assumptions, the persuasiveness and effectiveness of specific reasons is enhanced. This may disadvantage minority groups, since 'it is also the case that there are some basic factual and normative beliefs that most members of the majority society share, and that ethnocultural minorities may not generally hold these beliefs' (Valadez, 2001: 87). Despite her affinity with type I deliberation, Williams (1998: 144) refers to another limitation when a type I model is applied to the inclusion of disadvantaged groups: 'the status of marginalized groups as marginalized groups reflects, by definition, the fact that some of their fundamental interests are now systematically and unjustifiably neglected. Any discursive process in which that neglect come to light must make space for expression of group-specific interests'.

Indeed, a major challenge in current deliberative democracy is reconciling the two types of deliberation (Bächtiger et al., 2010a). There is agreement - even among difference democrats and feminists - that deliberative elements such as listening and respect are desirable features of the democratic process (see, e.g. Bickford, 1996: Ch. 5). But many scholars would simultaneously hold that this is desirable only in the context of ideal deliberative conditions where power relationships have been equalized. For disadvantaged groups and structural minorities, a brittle type I approach to deliberation may not do. Insisting on 'polite, orderly, dispassionate, gentlemanly argument' (Young, 2002: 49) in deliberation may create the perverse effect that more deliberation will undermine inclusionary goals. Therefore, in the context of disadvantaged groups and structural minorities, type I models of deliberation need 'friendly amendments' (see Adcock and Collier, 2001, for a similar concept in measurement theory) that reduce the normative burdens for disadvantaged discourse participants.

To be sure, attempts at reconciling the two types of deliberation must also take into account at which locus deliberation takes place. ${ }^{2}$ While varying levels of deliberative ability - such as the ability to present and understand rational

${ }^{2}$ We thank Ian O'Flynn for alerting us to this problématique. 
arguments - is paramount for citizen deliberation, this is not necessarily true in the context of political deliberation. Office holders are accomplished public speakers, irrespective of background. In other words, it would be foolish to assume that politicians from minority or disadvantaged groups would be lesssophisticated deliberators than those from majorities and advantaged groups. Thus, for deliberation among group representatives, the issue is not about the ability of different sorts of actors to deliberate well or poorly, but what to do about majorities having numbers on their side. In the following, we propose a deliberative approach that is adapted to deliberation among representatives of majority/advantaged groups and structural minorities/disadvantaged groups. It focuses on one key element of deliberation, namely reciprocity (which entails interactivity and respect). ${ }^{3}$

\section{Reciprocity}

According to Gutmann and Thompson (1996), reciprocity requires that participants offer reasons that other participants can accept. As such, reciprocity is a 'concept of mutual exchange' (Gutmann and Thompson, 1996: 55) entailing both interactivity and respect. It involves an effort to listen to and engage with people with whom we disagree and appreciate the moral force of their positions. At the same time, a focus on reciprocity addresses inclusion and exclusion in deliberative processes in novel ways. As Knight and Johnson (1997) have argued, the key criterion for equality in deliberation is not equal amounts of speaking time, but equal opportunity for political influence. By focusing on the (respectful) uptake of each other's arguments, reciprocity captures an important part of Knight and Johnson's (1997) standard.

Reciprocity has two components. First, it entails interactivity. This means that participants engage with each other, and that they do not only give reasons but listen and take up the reasons of other participants. As Goodin (2000: 91) notes, '[t]here must be uptake and engagement - other people must hear or read,

\footnotetext{
${ }^{3}$ To be sure, there are other deliberative standards such as justification rationality, common-good orientation, consensus orientation, and sincerity (or truthfulness). There are several reasons for dropping these standards from our analysis. First, justification rationality may not be of particular importance for minority-majority interaction in the political sphere. Second, common-good orientation is problematic since we would ban the expression of interests by minorities and disadvantaged groups. Moreover, references to the common good in politics are frequently not much more than 'cheap talk', being purely rhetorical and intended to attract potential voters. Third, agreement or consensus may be too remote to have empirical traction in real world politics. As Knight and Johnson (1997) argue, realistic conceptions of deliberation can produce compromises that rest on greater mutual understanding and respect. Finally, sincerity is the most problematic and disputed element of classic deliberation. On the one hand, it is extremely difficult to capture truthfulness or sincerity empirically, since true preferences are not directly observable. On the other hand, scholars have also questioned the importance of truthfulness for deliberative theory (see Markovits, 2006). Warren (2006: 177), for instance, makes a case for insincere 'good manners' in the context of sensitive issues and sensitive actor relationships. Here, participants 'self-censor and tell little white lies for the sake of discourse-enabling recognitions'. Insincere respect might sometimes help to advance the goals of deliberation - while sincerity might eventually stifle them.
} 
internalize and respond' for a process to be judged deliberative. Despite its crucial importance for deliberative theory, interactivity and 'listening' have been largely neglected in approaches to deliberation (see Dobson, 2010: 760). We attempt to rectify this deficiency by taking interactivity and listening seriously and developing appropriate empirical measures for it (see below). However, our attempt to capture 'listening' is only an approximation of the concept, since we focus on transcripts only. A full-blown analysis of 'listening' would require that we also explore whether participants have listened to others but do not explicitly report this. ${ }^{4}$

Second, reciprocity entails respect. According to Gutmann and Thompson (1996: 79), respect is a core principle of deliberative democracy. As Mansbridge et al. (2012: 11) note: 'being open to being moved by the words of another is to respect the other as a source of reasons, claims, and perspectives'. At the same time, mutual respect also implies non-domination 'because relationships of domination have already short-circuited mutual respect and, with this, deliberative influence' (Mansbridge et al., 2012: 11-12). Finally, respect also entails transformative power which many deliberationists view as the central goal of the process. In an experimental study, Schneiderhan and Khan (2008) found that the more respectful the discussion groups were, the more likely participants were to change their position.

However, as mentioned before, in the context of the inclusion of minorities and the disadvantaged, it would be unfair to expect that these groups must always be responsive and respectful toward the privileged, especially if there has been inequality in the past or if their vital interests are at stake. Thus, the 'burden of reciprocity' mainly falls on majorities and privileged groups. It is mainly their obligation to approach the claims of structural minorities and disadvantaged groups with serious listening and respect. Conversely, minorities are not held fully accountable to these standards. Of course, they may engage in a deliberative process, listen to majorities, and find out whether there are convincing arguments and solutions; however, they may also adopt a more passionate and adversarial stance vis-à-vis majorities and privileged groups. To illustrate what we mean by such differential deliberative expectations, we take the example of the routine renewal of a patent on the Confederate flag insignia in the U.S. Senate in July 1993 (see Gutmann and Thompson, 1996; Williams, 2000). Carol MoseleyBraun, the chamber's only black member, vigorously challenged the amendment on the basis that the Confederate flag insignia are a symbol of slavery. MoseleyBraun's emotional and angry speech provoked the Senate not only to take the issue seriously, but also led a majority of senators to vote against the amendment. Had Moseley-Braun acted in a type I deliberative way and used 'gentlemanly argument' - as her opponents in the Senate asked her to $\mathrm{do}^{5}$ - her minority

\footnotetext{
${ }^{4}$ We thank Graham Smith for highlighting this problem.

5 As Jesse Helms stated: 'I hope the Senator from Illinois has not embarked upon an inflammatory political gambit. We should avoid theatrics' (Senate Debate, July 22, 1993, S9255).
} 
perspective may not have produced the necessary awareness among other senators. At the same time, the Confederate flag insignia example is also instructive as to what the 'burden of reciprocity' of majorities and advantaged groups means in practice. Recognizing the historical oppression of African Americans, a considerable number of white as well as Southern senators not only listened carefully to Moseley-Braun but also acknowledged that the patent renewal was an issue of symbolism rather than routine. ${ }^{6}$

The relaxation of deliberative standards for structural minorities and disadvantaged groups is, however, conditional and partial. First, the less inequality experienced in the past and the less vital interests are at stake, the more we expect minorities to converge to the standards of majorities and privileged groups. Second, structural minorities and disadvantaged groups are also expected to treat majorities 'justly'. This means that minorities should not make demands that seriously compromize the 'basic well-being of the majority' (Valadez, 2001: 56) or other minorities. Acting otherwise would only replace past injustice with new injustice.

At this point, three clarifications are in order. First, our deliberative approach to inclusion is far from being 'condition-free'. Williams (1998) has noted that both the motivation for the privileged and institutional incentives may be crucial to realizing deliberative virtues. Concerning motivation, majorities must have a desire to be just and accommodative vis-à-vis structural minorities and disadvantaged groups; or, they must have an interest in avoiding conflict (Williams, 1998: 145). With regard to institutional preconditions, empirical research shows that the quality of deliberation is strongly tied to institutional incentives (Steiner et al., 2004). While some institutional arrangements - competitive settings with strong party discipline - undermine deliberative action (especially respect), others tend to favor it - such as more consensual settings with less party discipline. Thus, a realistic model of deliberative inclusion must take both actor motivation and institutional incentives seriously.

Second, our deliberative approach to minority inclusion focuses on process rather than on outcomes. While we agree that future research needs to study inclusion from an outcome perspective as well, we do not see a fundamental tension with a process approach to deliberation: the deliberative 'acting' of different group representatives may be indicative of their willingness to find a good and integrative solution to the problem (see Mutz, 2008). Indeed, the high quality of deliberation in one case under study - the language article debate - was conducive to a minority-favorable and consensual outcome.

Third, deliberationists are still defining what good deliberation means in absolute terms. Therefore, when analyzing the deliberative behavior of majorities and minorities, we do so only in relative terms - by comparing differences of reciprocity levels between majorities and minorities.

\footnotetext{
${ }^{6}$ Notice that Gutmann and Thompson (1996) use this example as an illustration for a good deliberative process.
} 


\section{Deliberative inclusion of linguistic minorities in Switzerland: an empirical test}

In the empirical part, we explore the deliberative ideal of reciprocity in the context of linguistic minorities in Switzerland. Switzerland is a multicultural state with four national languages: German, French, Italian, and Romansh. The German speakers form a structural majority (about $72.5 \%$ of the Swiss population), while the other linguistic groups form structural minorities. To be sure, the linguistic groups in Switzerland do not directly qualify as 'disadvantaged' groups (such as African Americans in the United States), since they have not experienced deep inequality or even oppression in the past. Moreover, they have always been included in the institutions of the Swiss state while enjoying a great deal of autonomy through the institutions of federalism. Especially in parliament (the object of our study), the criterion of 'external' inclusion is fulfilled. Since the linguistic groups are more or less concentrated in different cantons and members of parliament are elected in cantonal election districts, the linguistic groups are proportionally represented in the parliament. Nonetheless, when their vital interests are affected in national legislation, linguistic minorities have no formal means of veto power to prevent unwanted legislation but are generally dependent on the decisions of the German-speaking majority to realize their interests. Moreover, linguistic minorities have also regularly exhibited feelings of being marginalized, misunderstood, and ignored by German speakers (see Ceschi, 1991: 57; du Bois, 1999: 35ff.). In the context of national politics, finally, there is also an informal rule that every speaker uses his or her mother tongue, whereby working languages in the Parliament are German and French in committee debates and German, French, and Italian in plenary debates. ${ }^{7}$ Representatives from the French- and Italian-speaking parts may thus come up against the problem of being ignored by German speakers simply because the latter do not fully understand what they have said.

At the same time (and as a countervailing effect), there are also strong historical traditions of understanding and respect among the different language groups in Switzerland (Schmid, 1981). Political elites - and German-speaking elites in particular - generally have identity-based preferences for the maintenance of a multicultural Switzerland, leading them to 'depoliticize' linguistic conflicts and remain open to linguistic minorities' demands and arguments. The Swiss political system also counts a number of features that promote the inclusion of linguistic minorities: first, the party system is not organized along linguistic cleavages, reducing partisan incentives to politicize linguistic conflicts. Second, it is a nonparliamentary system, enabling individual legislators to engage in consequential deliberation. Third, it is a consensus system favoring integrative solutions; the consensus system is bolstered by direct democratic institutions that introduce uncertainty into the legislative process and thus provide incentives to find common solutions among the parties involved.

\footnotetext{
7 Only discussions in first chamber plenary debates are simultaneously translated.
} 
We think that the possibility of linguistic minority exclusion combined with the identity-based preferences of the German-speaking majority for minority inclusion as well as related institutional incentives make Switzerland a particularly interesting case to study the dynamics of deliberative inclusion. In the study of inclusion, there is an almost natural tendency to focus on those cases where inclusion is deficient. But when it comes to the demanding presuppositions of deliberative ideals (even in the context of a modified version as in our deliberative approach), we need to focus on potentially positive cases as well. Such cases can then serve, in principle, as evaluative benchmarks for cases where the histories of interaction as well as motivational and institutional conditions for the deliberative inclusion of structural minorities and disadvantaged groups are less favorable.

To our knowledge, this is also the first study to shed light on concrete interactions among linguistic elites in Switzerland. ${ }^{8}$ To date, scholars have focused on institutional and survey-based data in order to evaluate the degree of inclusion of linguistic minorities (see, e.g. Kübler et al., 2009 for the Swiss administration). But neither institutions nor representational devices pre-ordain inclusive behavior on the part of majorities. Furthermore, self-reported data as found in survey studies can be biased by issues of social desirability. Respondents may be unwilling to admit discriminatory attitudes when discrimination has become politically unacceptable (such as being openly discriminatory to linguistic minorities in the Swiss case). By focusing on detailed behavioral data (namely, transcripts of parliamentary debates) that illuminate how the German-speaking majority listens and talks to linguistic minorities (and vice versa) our study tries to overcome such deficiencies. This is particularly possible behind closed doors in committees where discussions are strictly confidential and speakers are guaranteed anonymity. However, one limitation of our study is that actors across linguistic groups may know each other well and may even be friends. We can partly control for such cross-linguistic ties by taking tenure (i.e. the amount of time a legislator has spent in parliament) and party affiliation into account. Yet a larger part of crosslinguistic ties remains unobservable, which limits the possibility of making causal inferences. Nonetheless, we think that our study represents a major improvement compared with existing studies on the inclusion of linguistic groups in Switzerland.

We analyze the deliberative behavior of the different linguistic groups in Swiss parliamentary debates in the non-public and public arenas of the first and second chambers. We focus on parliamentary debates for two reasons. First, Thompson (2008: 502) sees the essential aim of political deliberation as reaching binding decisions, a criterion that parliamentary debates fulfill. Second, there is also a practical reason for the focus on parliamentary debates: there are no other arenas or institutions where all language groups are present and interact with each other in the four national languages. In the civic sphere, these conditions are rarely

\footnotetext{
${ }^{8}$ While the Steiner et al. (2004) study includes linguistic issues in Switzerland, it does not take an indepth look at these debates.
} 
(if ever) met. Thus, consequential multilingual deliberation in Switzerland on political issues almost exclusively occurs at the elite level. Finally, some may object that parliament is not the right locus for studying deliberative inclusion, since parliamentary debate is conducted in a competitive, adversarial, and rhetorical manner. Moreover, if legislators enter into policy negotiations then this is understood as bargaining rather than deliberation. But such statements do not consider the fact that this role depends on institutional factors, as well as on issue characteristics. As we have argued above, the institutional architecture of the Swiss parliament is generally favorable to a deliberative mode of interaction, especially behind closed doors.

A central goal of our study is to determine the extent of the deliberative inclusion (or exclusion) of linguistic minorities in parliamentary debates. We also want to shed some light on the contexts of deliberative inclusion or exclusion. To do so, we focus, first of all, on the distinction between non-public committee and plenary debates. In this regard, the non-public committee stage enables us to explore deliberative inclusion when consequential decisions are crafted. In contrast, the public plenary stage enables us to explore deliberative inclusion when political actors justify their decisions before the wider public and their constituencies. Drawing from empirical approaches to deliberation (see Stasavage, 2007) as well as consociational theory (Lijphart, 1977), we expect that political actors are less inclusive in the public sphere than in the non-public sphere. In the public sphere, political actors need to act as representatives of their groups and must serve constituency interests. Even though the party system barely reflects linguistic cleavages, individual MPs might still have some incentive to present themselves as advocates of their territorially based constituencies, which in Switzerland are language based. By contrast, in the non-public sphere, politicians can deliberate without external interference, making it easier for them to show respect for the claims of others and accommodate minority interests. Consociational scholars, too, have repeatedly stressed that a 'spirit of accommodation' among different segments of society flourishes best behind closed doors. Second, we also consider different types of issues. If there is some motivation for majorities to include minority demands, then we expect that reciprocity toward minorities is more prevalent in the context of issues that touch upon the vital interests of minorities. This expectation is in line with our modified deliberative approach: the more vital interests of structural minorities are affected, the more majorities are expected to listen and respond to minorities. ${ }^{9}$ There is also some empirical evidence for this claim. In a

\footnotetext{
${ }^{9}$ In this article, we do not consider the familiar distinction between statistical and taste-based discrimination. To be sure, the data would lend itself to such an analysis: we could distinguish among minority actors speaking in French or Italian (French and Italian speakers) and minority actors speaking in German (in the Swiss parliament, this is the case for Romansh speakers and some bi-lingual speakers) and then evaluate whether the German-speaking majority listens mainly to those minority actors speaking in the majority language (German); this then would classify as statistical discrimination. However, since there are almost no discriminatory effects against minority speakers in the parliamentary debates that we analyzed (see 'Results' in next section), such an analysis becomes obsolete. Conversely, the lack of
} 
laboratory experiment, Espinoza and Garza (1985) explored the effect of social group salience among Hispanics and Anglo-Americans on the cooperative-competitive behavior of subjects. They found that in a high salience condition, majority group members (Anglo subjects) were more cooperative than minority group members (Hispanic subjects).

Concretely, we analyze two debates on linguistic policies, which touch upon vital interests of linguistic minorities: the language article of the 1990s (Sprachenartikel) and the language bill of the 2000s (Sprachengesetz). In addition, we focus on a contrasting debate, the labor law revision (Arbeitsgesetz) of the 1990s, which does not touch upon vital interests of the linguistic minorities. Let us briefly give some background on these debates.

\section{Language article}

The goal of the new language article was to improve the position of the Romansh language and thus concerned with the flourishing of this tiny linguistic minority in Switzerland. The government proposed an amendment that made explicit reference both to the principle of the freedom of language and the territoriality principle (stipulating that people who belong to another linguistic region must not be instructed in their classes in any other language). 'Weakening' the territoriality principle would provide Romansh speakers with more flexibility to preserve their language. However, French- and Italian-speaking deputies argued that codifying the territoriality principle in the Constitution would involve unforeseeable dangers for linguistic peace since German speakers might ask for German schools in the Frenchor Italian-speaking cantons. Finally, a compromize proposal found approval: none of the principles would be mentioned in the constitution, but the central state would help endangered linguistic minorities if cantons asked. The bill passed with 152-19 votes in the first chamber and 43-0 votes in the second chamber.

\section{Language bill}

After the rejection of a new language bill by the government in 2004, the committee of the first chamber decided to draw up a new version of the language bill. The goal of the bill was to secure national cohesion as well as communication between the different linguistic groups. Article 15 of the new bill, regulating language instructions in school, was one of the most disputed articles. The first chamber decided in favor of prioritizing a national language, rather than English, as the first foreign language in school. The second chamber, however, supported a proposal of the Swiss Conference of Cantonal Ministers of Education. ${ }^{10}$ This proposal implied that of the two foreign

\footnotetext{
discrimination cannot be ascribed to German-speaking minority actors (such as Romansh or bi-lingual speakers) either. We have performed a batch of re-analyses showing that reciprocity rates are not affected by the language spoken (analyses available upon request).

10 Schweizerische Konferenz der kantonalen Erziehungsdirektoren (EDK).
} 
languages that should be learned in school, at least one should be a national language, yet the cantons should be free to decide whether it is taught as the first language. In order to avoid a language dispute between the linguistic communities, a compromize solution was finally approved. The compromize solution required that students should have competencies in the basics of two foreign languages and that at least one of them should be a national language. The bill passed with 135-56 votes in the first chamber and 39-0 votes in the second chamber.

\section{Labor law revision}

The labor law revision aimed at overhauling certain labor regulations and improving the competitiveness of the Swiss economy. Two articles of the bill were seen as critical during discussions: Article 17, dealing with night work for women, and Article 20, dealing with work on Sundays and official holidays. The goal of the new Article 17 was to establish gender equality, especially by abolishing the ban on women working at night. The government also proposed a $10 \%$ time bonus for regular work at night and on Sundays. The bill was challenged by a group of right-wing deputies arguing that the compensation measures were too far-reaching. Left-wing deputies supported the governmental proposal. The aim of the new Article 20 was to revise trading times with the goal of having longer opening times on Sundays and during holidays. No compromize could be found after lengthy negotiations, and when the Swiss Federation of Trade Unions started collecting signatures for a referendum, most rightwing deputies gave up any search for a compromize. The bill was rejected in the final vote by $89-80$ in the first chamber and $27-6$ in the second chamber.

We limit our study to three cases since an in-depth coding of reciprocity patterns is a highly demanding and time-consuming affair. While this precludes our ability to make sweeping generalizations, the three cases nonetheless constitute crucial cases in Switzerland: the two linguistic debates are the only major debates on linguistic policy that have taken place since 1938, when Romansh was recognized as the fourth national language. The labor law, in turn, constitutes one of the key decision cases in Switzerland in the 1990s (see Linder, 2005). Moreover, the high degree of partisan polarization in this debate is in stark contrast with the largely non-partisan approach in the two linguistic decision cases. Party polarization, in turn, may offset motivations for the explicit inclusion of linguistic minorities. We think that these three crucial cases can give important first hints regarding the extent and the contexts of the deliberative inclusion of Swiss linguistic minorities.

\section{Methodology}

Our empirical analysis of deliberative inclusion draws on Steven Levitt's (2004) analysis of discrimination in the United States. Levitt used the television game show 'Weakest Link' to test for discrimination patterns among contestants. To measure discrimination, Levitt uses the number of votes a contestant receives as a function of 
his personal characteristics (race, gender, age), controlled for other factors (such as performance of a contestant in the game show): if race, gender, or age yields statistically significant effects, then Levitt speaks of discrimination. We use parliamentary committee and plenary debates to calculate frequencies of reciprocity rates as a function of the minority or majority status of the speaker, controlling for other characteristics of the speaker (such as gender, role, or partisan affiliation) as well as context characteristics (issues, plenary sessions vs. committees, and first vs. second chamber). Deliberative inclusion is present when there are no statistically significant differences in reciprocity levels between structural minorities and majorities. Moreover, following our 'friendly amendment', reciprocity from majorities toward minorities should be at least equal or even slightly biased in favor of minorities, that is, majority actors may refer slightly more frequently and more respectfully to minority actors than vice versa. As detailed before, we want this to be the case especially when vital interests of structural minorities are at stake. Since linguistic minorities in Switzerland are not severely disadvantaged groups, the 'burden of reciprocity' of the Germanspeaking majority cannot be too high.

To measure reciprocity, we have developed an indicator measuring whether participants respond to other participants' demands and arguments and whether this response is explicitly respectful, neutral, or disrespectful (for detailed coding see Appendix 3 in the online material). Only references to MPs and Federal Councillors are coded. Furthermore, we also coded who made references to whom, and whether that reference was clear. If other participants were only mentioned in connection with a proposal they submitted, they were not coded. Simple references such as thanks, questions, and requests were not coded either. We analyzed about 400 parliamentary speeches, with very respectable reliability scores for our reciprocity measures: Cohen's kappa, which controls for inter-coder agreements by chance, is 0.82 for the response measure [i.e. whether participants responded to each other's arguments (or, not)] and 0.80 for the respect measures (i.e. whether the response was explicitly respectful, neutral, or disrespectful).

Table 1 presents the matrix of incoming and outgoing references (including respectful, neutral, and disrespectful references) of one committee session on the language article (confidentiality requires that speaker names as well as the exact date of the session are omitted). The shaded cells denote minority speakers (French, Italian, or Romansh speakers).

On the basis of this matrix, we calculate different measures for incoming and outgoing references. A first measure concerns the frequency of incoming references and the frequency of outgoing references. We calculate how often the arguments of minorities and majorities are referred to (incoming references) and how often minorities and majorities refer to other participants' arguments (outgoing references). In this example, actor B's arguments (a minority actor) are referred to 9 times ('in'); at the same time, actor B does not make any reference to other participants' arguments ('out') but speaks up 3 times ('nr_speech'). For the incoming references, we need to take into account how often a person speaks: if a person does not make a single speech (such as actor U), 
Table 1. Matrix of incoming and outgoing references; example from a committee session

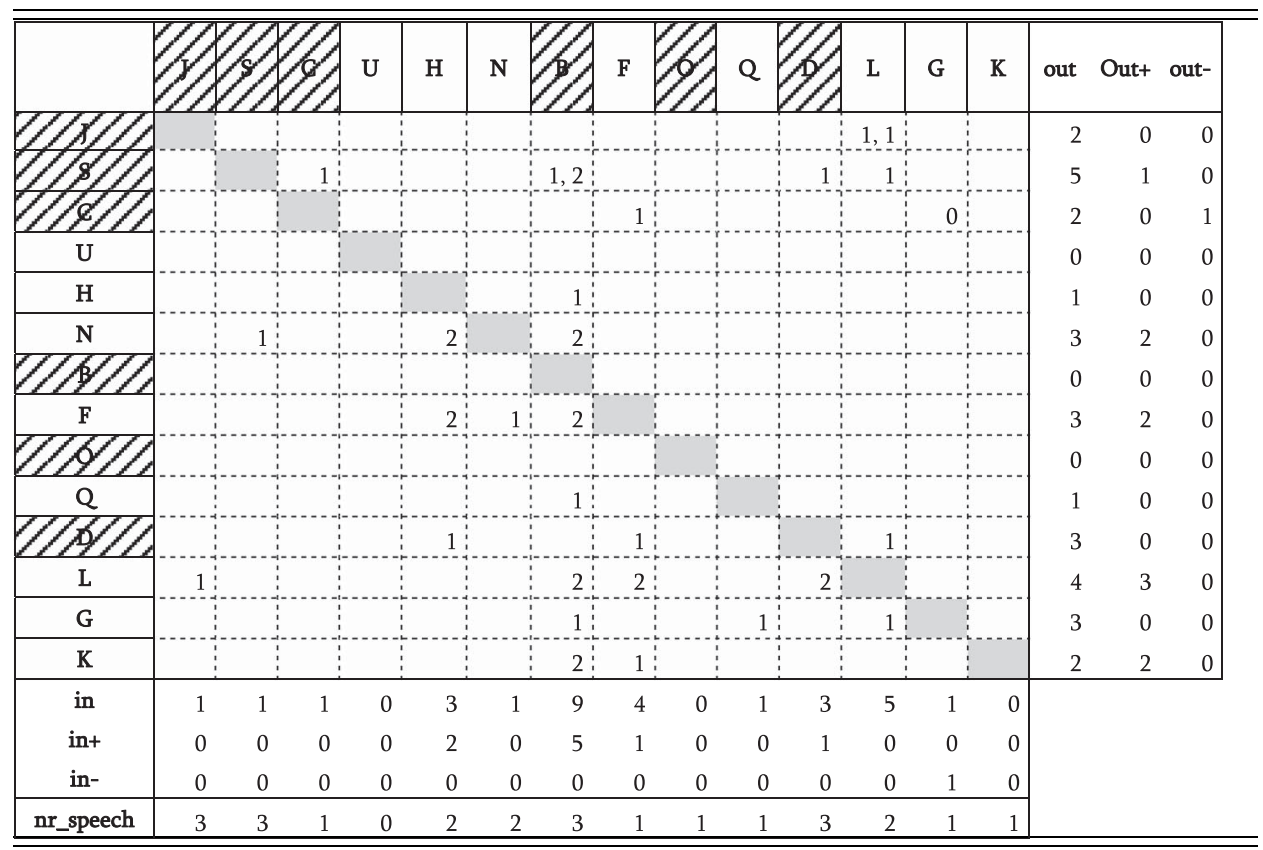

Notes: $0=$ disrespectful reference; $1=$ neutral reference; $2=$ respectful reference; in $=$ number of incoming references; in $+=$ number of respectful incoming references; in $-=$ number of disrespectful incoming references; out $=$ number of outgoing references; out $+=$ number of respectful outgoing references; out $-=$ number of disrespectful outgoing references; $\mathrm{nr}$ _speech $=$ total number of speeches (including references and other speeches). Shaded cells denote minority actors.

then other persons cannot refer to his or her arguments. Thus, completely 'silent' actors are excluded from the analysis. In addition, the more frequently an actor speaks, the higher the chances that his or her arguments will be referred to. Similarly, the more an actor speaks the higher the chances that he or she will refer to another actor. Therefore, we need to weight the incoming and outgoing references by the number of speeches. We do so by using the number of speeches as a predictor in the statistical analysis. ${ }^{11}$

A second batch of measures focuses on the frequency of positive and negative incoming references and the frequency of positive and negative outgoing references. We calculate how often the arguments of minorities and majorities are referred to in a positive or negative way and how often minorities and majorities refer to

\footnotetext{
11 Since this produces endogeneity between the predictor and outcome variable in the statistical analysis, we have also considered another weighting procedure - dividing incoming or outgoing references by the number of speeches. However, this makes all predictor variables dependent on the number of speeches, producing biased results for some predictor variables. Thus, we prefer the first weighting procedure.
} 
other participants' arguments in a positive or negative way. Again, we need to take into account frequencies of incoming and outgoing references by using the number of (positive and negative) incoming and outgoing references as predictors in the statistical analysis.

So far, we have only considered the total number of incoming and outgoing references, without analyzing whether these references come from linguistic minorities or majorities. However, we may come across a situation where we find seemingly nondiscriminatory patterns of reciprocity which may, however, be produced by minorities only referring to minorities and majorities only referring to majorities, without any exchange between majorities and minorities. To analyze whether and how often majorities refer to minorities' arguments (and vice versa), we have created a third measure of reciprocity, which we dub 'Incoming References from Same Group'. This measure is an index and is constructed in a straightforward and simple way. For minorities, the number of incoming references that a minority actor gets from other minority actors is divided by the total number of incoming references of this actor. For majorities, the number of incoming references that a majority actor gets from other majority actors is divided by total number of incoming references of this actor. If the incoming references of a minority actor come only from minorities, then this actor obtains a score of 1 . Take actor $\mathrm{C}$ (a minority actor): his arguments are only referred to once by actor $\mathrm{S}$ who is a minority actor as well; hence, actor $\mathrm{C}$ gets a score of 1 . Conversely, if the incoming references of a minority actor only come from majority actors, then this person obtains a score of 0 . If the incoming references come both from majority and minority actors, we calculate a percentage rate. Take actor $\mathrm{B}$, a minority actor: he gets a total of 9 incoming references; 2 out of the 9 incoming references come from minority actors, 7 from majority actors; hence, he gets a score of 0.22 (indicating that there is a lot of cross-group referencing). In sum, scores closer to 1 indicate that there is primarily same-group referencing; scores closer to 0 indicate that there is primarily cross-group referencing. The same procedure applies to incoming positive and negative references and outgoing positive and negative references. A final problem concerns the relationship of the index and the frequency of incoming references. There is a possibility that the more incoming references (including positive and negative ones) an actor gets, the more incoming references (including positive and negative ones) will come from different groups. We control for this by using the number of incoming references as a predictor in our statistical models. ${ }^{12}$ Descriptive statistics for the outcome variables are reported in Appendix 1. ${ }^{13}$

12 Of course, there are other ways to explore the concept of 'Incoming/Outgoing References from/to Same Group', namely by tools developed in the context of network analysis. For instance, both the 'quadratic assignment procedure' (QAP) and 'exponential random graph models' (ERGM; Lazer et al., 2010) can be used to test for so-called 'homophily' effects, measuring the tendency for similar individuals to form a tie in a network (see Gerber, 2012). Nonetheless, we think that our approach provides us with more 'flexibility' in statistical analysis, especially by enabling us to run complex interactions of our reciprocity measures with contextual variables.

13 Available on the journal website. 
Our statistical models control for a number of factors that may affect the participation and reciprocity levels of minority and majority speakers and that previous research has identified as important for the quality of deliberation in parliaments (see Steiner et al., 2004; Bächtiger and Hangartner, 2010): gender, age, tenure, roles (chairperson, committee spokesperson, and Federal Councillor), partisan affiliations, institutional contexts (public vs. non-public arenas and first vs. second chambers), and different issues (a description of the variables is provided in Appendix 2). ${ }^{14}$ Psychologists also argue that proportion of minorities in decision-making groups might affect the way these groups operate (Mendelberg and Karpowitz, 2007), which in turn may affect our measures of deliberative inclusion. Indeed, there is substantial variation in the minority/majority composition of committees and plenary sessions: in our sample of parliamentary debates, the proportion of members from linguistic minorities ranges between $14 \%$ and $53 \%$. However, the proportion of linguistic minorities in committees and plenary sessions is highly collinear with issue type: in concrete, the proportion of minorities is higher for linguistic issues. Therefore, we do not insert issue type and group composition in the same statistical model.

To explore the contexts of deliberative inclusion, we include two interaction terms in the models, namely between vital issues (language article and language law) and linguistic minorities as well as between non-publicity and linguistic minorities. Since the reciprocity levels are calculated on the basis of the different sessions of the debate, we use clustered standard errors at the level of the sessions that take into account the fact that errors may not be independent within different sessions. We refrain from including debate sessions as fixed effects in our models, since debate sessions are highly collinear with a number of contextual control variables. The results are reported from negative binomial, Poisson, and Beta specifications. The negative binomial and Poisson specifications incorporate the fact that our reciprocity variables are count data. By using the negative binomial, we take into account that some of the outcome variables are over-dispersed, that is, the conditional variance exceeds the conditional mean (Long, 1997). ${ }^{15}$ The Beta specifications, in turn, incorporate the fact that our index of same group references is a proportion that is bounded between 0 and 1 and follows a U-shaped distribution. For such ratios, Beta regression is more appropriate than ordinary least square regression. The random variable for a Beta is continuous from 0 to 1 and the Beta distribution is bounded between 0 and 1 (but does not include 0 or 1 ; $^{16}$ see Ferrari and Cribari-Neto, 2004).

14 Available on the journal website.

${ }^{15}$ We have run a number of robustness checks. First, we calculated random effects for all the models. Results did not change. Second, we also ran zero-inflated negative poisson models for the negative outgoing and negative incoming models in order to account for excessive zero counts. Again, the results did not differ from the poisson models.

16 Therefore, we have rescaled 0s into 0.0000000001 and 1 s into 0.9899999999. 


\section{Results}

Tables 2 and 3 present the regression results for the various indicators of reciprocity. First, focusing on average effects of incoming and outgoing references, there are no statistically reliable differences between minority and majority speakers. There are, however, some statistically significant interactive effects between minority status and issue type, both for ingoing and outgoing references. Compared with the labor law debate, minorities receive more incoming references in the context of the two linguistic debates, while simultaneously making slightly more outgoing references under the latter conditions. However, the interactive effects are substantively small and in the case of outgoing references also only marginally significant.

Another aspect of reciprocity is whether different groups are treated with respect. On average, the analyses for positive and negative incoming and outgoing references display few differences between minority and majority actors. However, there is a positive and statistically significant interactive effect between minority status and issue type for outgoing negative references. This implies that in the two linguistic debates minority actors refer more negatively to other actors than in the labor law debate. This result is in line with our modified deliberative approach, explicitly allowing minorities to take a more passionate and adversarial stance when their vital interests are concerned.

These analyses of reciprocity, however, only give information on the overall deliberative performance of minority and majority actors. We also need to look at reciprocity, focusing on how often linguistic minorities are referred to by the German-speaking majority (and vice versa). To do so, we have created an index capturing whether there is primarily same-group interaction (with scores going to 1 ) or cross-group interaction (with scores going to 0 ). Looking at the raw figures of the index (see Appendix 1), ${ }^{17}$ the picture looks quite bright: for incoming references, minorities reach an average score of 0.58 , whereas the Germanspeaking majority reaches an average score of 0.65 . For outgoing references, the respective scores are 0.56 and 0.59 . These figures show that there is substantial degree of cross-referencing between the German-speaking majority and linguistic minorities. This is also corroborated by the statistical models in Tables 4 and 5 . First, with regard to incoming references from same group (model 7a) there are no statistically significant differences between linguistic minorities and the Germanspeaking majority. Second, for positive incoming reciprocity (model 8a), we even find a statistically negative effect of minority speakers, indicating that linguistic minorities receive more respectful references from the German-speaking majority than vice versa.

In addition, there are a number of interactive effects. For the index of 'incoming references of same group' (model $7 \mathrm{~b}$ ), the interaction terms between minority

17 Available on the journal website. 
Table 2. Measures of reciprocity

\begin{tabular}{|c|c|c|c|c|c|c|}
\hline & $\begin{array}{l}\text { Model 1a } \\
\text { Incoming } \\
\text { references }\end{array}$ & $\begin{array}{l}\text { Model 1b } \\
\text { Incoming } \\
\text { references }\end{array}$ & $\begin{array}{l}\text { Model 2a } \\
\text { Outgoing } \\
\text { references }\end{array}$ & $\begin{array}{c}\text { Model 2b } \\
\text { Outgoing } \\
\text { references }\end{array}$ & $\begin{array}{l}\text { Model 3a } \\
\text { Positive } \\
\text { incoming } \\
\text { references }\end{array}$ & $\begin{array}{l}\text { Model 3b } \\
\text { Positive } \\
\text { incoming } \\
\text { references }\end{array}$ \\
\hline Minority Speakers & $\begin{array}{c}0.12 \\
(0.09)\end{array}$ & $\begin{array}{r}-0.30 \\
(0.19)\end{array}$ & $\begin{array}{r}-0.10 \\
(0.12)\end{array}$ & $\begin{array}{c}-0.51+ \\
(0.27)\end{array}$ & $\begin{array}{c}0.21 \\
(0.23)\end{array}$ & $\begin{array}{c}0.39 \\
(0.45)\end{array}$ \\
\hline Language Article & $\begin{array}{c}0.03 \\
(0.13)\end{array}$ & $\begin{array}{c}-0.09 \\
(0.14)\end{array}$ & $\begin{array}{c}0.05 \\
(0.13)\end{array}$ & $\begin{array}{c}-0.15 \\
(0.17)\end{array}$ & $\begin{array}{c}0.16 \\
(0.25)\end{array}$ & $\begin{array}{c}0.13 \\
(0.42)\end{array}$ \\
\hline Language Law & $\begin{array}{c}0.20 \\
(0.13)\end{array}$ & $\begin{array}{c}0.03 \\
(0.15)\end{array}$ & $\begin{array}{c}0.34 * \\
(0.14)\end{array}$ & $\begin{array}{c}0.14 \\
(0.19)\end{array}$ & $\begin{array}{c}0.54+ \\
(0.30)\end{array}$ & $\begin{array}{c}0.76 * \\
(0.36)\end{array}$ \\
\hline $\begin{array}{l}\text { Minority } \times \text { Language } \\
\text { Article }\end{array}$ & & $\begin{array}{c}0.35+ \\
(0.21)\end{array}$ & & $\begin{array}{c}0.56+ \\
(0.30)\end{array}$ & & $\begin{array}{r}-0.04 \\
(0.67)\end{array}$ \\
\hline $\begin{array}{l}\text { Minority } \times \text { Language } \\
\text { Bill }\end{array}$ & & $\begin{array}{l}0.43 * \\
(0.21)\end{array}$ & & $\begin{array}{c}0.53+ \\
(0.30)\end{array}$ & & $\begin{array}{r}-0.52 \\
(0.51)\end{array}$ \\
\hline Non-Public Arena & $\begin{array}{c}0.03 \\
(0.12)\end{array}$ & $\begin{array}{r}-0.05 \\
(0.14)\end{array}$ & $\begin{array}{r}-0.05 \\
(0.12)\end{array}$ & $\begin{array}{c}-0.04 \\
(0.17)\end{array}$ & $\begin{array}{r}-0.23 \\
(0.28)\end{array}$ & $\begin{array}{r}-0.27 \\
(0.41)\end{array}$ \\
\hline $\begin{array}{l}\text { Minority } \times \text { Non- } \\
\text { Public Arena }\end{array}$ & & $\begin{array}{c}0.15 \\
(0.13)\end{array}$ & & $\begin{array}{r}-0.04 \\
(0.20)\end{array}$ & & $\begin{array}{c}0.12 \\
(0.43)\end{array}$ \\
\hline Second Chamber & $\begin{array}{c}0.23 * \\
(0.11)\end{array}$ & $\begin{array}{c}0.25 \% \\
(0.11)\end{array}$ & $\begin{array}{c}0.21+ \\
(0.11)\end{array}$ & $\begin{array}{c}0.21+ \\
(0.11)\end{array}$ & $\begin{array}{c}0.28 \\
(0.23)\end{array}$ & $\begin{array}{c}0.25 \\
(0.23)\end{array}$ \\
\hline CVP & $\begin{array}{c}-0.21+ \\
(0.13)\end{array}$ & $\begin{array}{c}-0.25 * \\
(0.13)\end{array}$ & $\begin{array}{c}-0.20+ \\
(0.11)\end{array}$ & $\begin{array}{c}-0.25 * \\
(0.11)\end{array}$ & $\begin{array}{c}0.32 \\
(0.25)\end{array}$ & $\begin{array}{c}0.37 \\
(0.29)\end{array}$ \\
\hline SP & $\begin{array}{c}-0.04 \\
(0.15)\end{array}$ & $\begin{array}{r}-0.05 \\
(0.14)\end{array}$ & $\begin{array}{r}-0.16 \\
(0.14)\end{array}$ & $\begin{array}{r}-0.17 \\
(0.14)\end{array}$ & $\begin{array}{c}0.02 \\
(0.26)\end{array}$ & $\begin{array}{c}0.02 \\
(0.27)\end{array}$ \\
\hline SVP & $\begin{array}{r}-0.03 \\
(0.12)\end{array}$ & $\begin{array}{r}-0.03 \\
(0.12)\end{array}$ & $\begin{array}{r}-0.08 \\
(0.14)\end{array}$ & $\begin{array}{r}-0.08 \\
(0.14)\end{array}$ & $\begin{array}{c}0.04 \\
(0.25)\end{array}$ & $\begin{array}{c}0.04 \\
(0.25)\end{array}$ \\
\hline Greens & $\begin{array}{c}0.04 \\
(0.16)\end{array}$ & $\begin{array}{c}0.03 \\
(0.16)\end{array}$ & $\begin{array}{c}0.05 \\
(0.23)\end{array}$ & $\begin{array}{c}0.06 \\
(0.23)\end{array}$ & $\begin{array}{r}-0.76 \\
(0.78)\end{array}$ & $\begin{array}{r}-0.67 \\
(0.78)\end{array}$ \\
\hline EDU/EVP/LIB/LDU & $\begin{array}{r}-0.15 \\
(0.16)\end{array}$ & $\begin{array}{r}-0.17 \\
(0.16)\end{array}$ & $\begin{array}{c}0.02 \\
(0.22)\end{array}$ & $\begin{array}{c}0.01 \\
(0.21)\end{array}$ & $\begin{array}{c}0.27 \\
(0.36)\end{array}$ & $\begin{array}{c}0.34 \\
(0.40)\end{array}$ \\
\hline AP/LEGA & $\begin{array}{r}-0.15 \\
(0.22)\end{array}$ & $\begin{array}{r}-0.24 \\
(0.21)\end{array}$ & $\begin{array}{r}-0.33 \\
(0.44)\end{array}$ & $\begin{array}{r}-0.40 \\
(0.44)\end{array}$ & $\begin{array}{c}0.09 \\
(0.67)\end{array}$ & $\begin{array}{c}0.19 \\
(0.66)\end{array}$ \\
\hline $\begin{array}{l}\text { Committee } \\
\text { Spokesperson }\end{array}$ & $\begin{array}{c}0.17 \\
(0.23)\end{array}$ & $\begin{array}{c}0.17 \\
(0.23)\end{array}$ & $\begin{array}{c}0.36+ \\
(0.19)\end{array}$ & $\begin{array}{c}0.36^{*} \\
(0.18)\end{array}$ & $\begin{array}{c}-0.09 \\
(0.31)\end{array}$ & $\begin{array}{r}-0.11 \\
(0.29)\end{array}$ \\
\hline Chairperson & $\begin{array}{l}-1.00 * * \\
(0.29)\end{array}$ & $\begin{array}{l}-0.97 * * \\
(0.28)\end{array}$ & $\begin{array}{l}-0.53^{* *} \\
(0.20)\end{array}$ & $\begin{array}{c}-0.52 * * \\
(0.20)\end{array}$ & $\begin{array}{r}-0.53 \\
(0.44)\end{array}$ & $\begin{array}{r}-0.52 \\
(0.45)\end{array}$ \\
\hline Federal Councillor & $\begin{array}{r}-0.07 \\
(0.24)\end{array}$ & $\begin{array}{c}-0.05 \\
(0.24)\end{array}$ & $\begin{array}{l}0.96 * * \\
(0.15)\end{array}$ & $\begin{array}{l}1.01 * * \\
(0.16)\end{array}$ & $\begin{array}{c}0.21 \\
(0.43)\end{array}$ & $\begin{array}{c}0.35 \\
(0.37)\end{array}$ \\
\hline Age & $\begin{array}{r}-0.00 \\
(0.00)\end{array}$ & $\begin{array}{r}-0.00 \\
(0.00)\end{array}$ & $\begin{array}{c}-0.02 * \\
(0.01)\end{array}$ & $\begin{array}{c}-0.02 * * \\
(0.01)\end{array}$ & $\begin{array}{r}-0.02 \\
(0.02)\end{array}$ & $\begin{array}{r}-0.02 \\
(0.02)\end{array}$ \\
\hline Tenure & $\begin{array}{r}-0.00 \\
(0.01)\end{array}$ & $\begin{array}{r}-0.00 \\
(0.01)\end{array}$ & $\begin{array}{l}0.02 * * \\
(0.01)\end{array}$ & $\begin{array}{l}0.02 * * \\
(0.01)\end{array}$ & $\begin{array}{r}-0.00 \\
(0.02)\end{array}$ & $\begin{array}{c}0.01 \\
(0.02)\end{array}$ \\
\hline Gender & $\begin{array}{l}-0.42 * * \\
(0.11)\end{array}$ & $\begin{array}{l}-0.41 * * \\
(0.11)\end{array}$ & $\begin{array}{r}-0.09 \\
(0.10)\end{array}$ & $\begin{array}{r}-0.09 \\
(0.09)\end{array}$ & $\begin{array}{r}-0.07 \\
(0.22)\end{array}$ & $\begin{array}{r}-0.14 \\
(0.23)\end{array}$ \\
\hline Number of speeches & $\begin{array}{l}0.19 * * \\
(0.02)\end{array}$ & $\begin{array}{l}0.19 * * \\
(0.02)\end{array}$ & $\begin{array}{l}0.18 * * \\
(0.02)\end{array}$ & $\begin{array}{l}0.18 * * \\
(0.02)\end{array}$ & & \\
\hline $\begin{array}{l}\text { Number of incoming } \\
\text { references }\end{array}$ & & & & & $\begin{array}{l}0.31 * * \\
(0.02)\end{array}$ & $\begin{array}{l}0.31 * * \\
(0.03)\end{array}$ \\
\hline Constant & $\begin{array}{r}-0.17 \\
(0.34)\end{array}$ & $\begin{array}{c}0.11 \\
(0.33)\end{array}$ & $\begin{array}{c}0.36 \\
(0.36)\end{array}$ & $\begin{array}{c}0.63 \\
(0.39)\end{array}$ & $\begin{array}{c}-1.67^{*} \\
(0.81)\end{array}$ & $\begin{array}{r}-1.82 * \\
(0.87)\end{array}$ \\
\hline
\end{tabular}


Table 2. (Continued)

\begin{tabular}{|c|c|c|c|c|c|c|}
\hline & $\begin{array}{l}\text { Model 1a } \\
\text { Incoming } \\
\text { references }\end{array}$ & $\begin{array}{l}\text { Model 1b } \\
\text { Incoming } \\
\text { references }\end{array}$ & $\begin{array}{l}\text { Model 2a } \\
\text { Outgoing } \\
\text { references }\end{array}$ & $\begin{array}{l}\text { Model 2b } \\
\text { Outgoing } \\
\text { references }\end{array}$ & $\begin{array}{l}\text { Model 3a } \\
\text { Positive } \\
\text { incoming } \\
\text { references }\end{array}$ & $\begin{array}{l}\text { Model 3b } \\
\text { Positive } \\
\text { incoming } \\
\text { references }\end{array}$ \\
\hline$\alpha$ & $\begin{array}{l}0.32 * * \\
(0.07)\end{array}$ & $\begin{array}{l}0.31 * \\
(0.07)\end{array}$ & $\begin{array}{l}0.22 * \\
(0.06)\end{array}$ & $\begin{array}{l}0.22 * * \\
(0.05)\end{array}$ & & \\
\hline Log-likelihood & -975.42 & -972.92 & -933.57 & -930.14 & -300.86 & -300.06 \\
\hline $\mathrm{BIC}$ & 2079.44 & 2093.73 & 1995.73 & 2008.16 & 723.89 & 741.05 \\
\hline$N$ & 620 & 620 & 620 & 620 & 620 & 620 \\
\hline Method & $\begin{array}{l}\text { Negative } \\
\text { Binomial }\end{array}$ & $\begin{array}{l}\text { Negative } \\
\text { Binomial }\end{array}$ & $\begin{array}{l}\text { Negative } \\
\text { Binomial }\end{array}$ & $\begin{array}{l}\text { Negative } \\
\text { Binomial }\end{array}$ & Poisson & Poisson \\
\hline
\end{tabular}

Notes: Estimated standard errors (clustered at the level of debate sequences) are shown in parentheses.

$* * P<0.01, * P<0.05,+P<0.10$.

Table 3. Measures of reciprocity cont.

\begin{tabular}{lcccccc}
\hline \hline & $\begin{array}{c}\text { Model 4a } \\
\text { Negative } \\
\text { incoming } \\
\text { references }\end{array}$ & $\begin{array}{c}\text { Model 4b } \\
\text { Negative } \\
\text { incoming } \\
\text { references }\end{array}$ & $\begin{array}{c}\text { Model 5a } \\
\text { Positive } \\
\text { outgoing } \\
\text { references }\end{array}$ & $\begin{array}{c}\text { Model 5b } \\
\text { Positive } \\
\text { outgoing } \\
\text { references }\end{array}$ & $\begin{array}{c}\text { Model 6a } \\
\text { Negative } \\
\text { outgoing } \\
\text { references }\end{array}$ & $\begin{array}{c}\text { Model 6b } \\
\text { Negative } \\
\text { outgoing } \\
\text { references }\end{array}$ \\
\hline Minority Speakers & 0.25 & 0.16 & -0.33 & $-0.81^{* *}$ & -0.31 & $-1.95^{* *}$ \\
Language Article & $(0.19)$ & $(0.28)$ & $(0.21)$ & $(0.29)$ & $(0.28)$ & $(0.56)$ \\
& $-0.85^{*}$ & $-1.17+$ & -0.05 & -0.33 & -0.51 & $-0.92^{* *}$ \\
Language Law & $(0.43)$ & $(0.60)$ & $(0.24)$ & $(0.27)$ & $(0.33)$ & $(0.32)$ \\
& $-0.78^{*}$ & -0.47 & $0.44+$ & 0.39 & $-0.88^{* *}$ & $-1.72^{* *}$ \\
Minority $\times$ Language & $(0.31)$ & $(0.40)$ & $(0.22)$ & $(0.25)$ & $(0.31)$ & $(0.51)$ \\
Article & & 0.66 & & $1.00^{*}$ & & $1.51^{* *}$ \\
Minority $\times$ Language & & $(0.51)$ & & $(0.46)$ & & $(0.48)$ \\
Bill & & -0.61 & & 0.27 & & $2.13^{* *}$ \\
Non-Public Arena & -0.43 & $-0.51)$ & -0.09 & -0.14 & -0.08 & -0.32 \\
& $(0.31)$ & $(0.39)$ & $(0.24)$ & $(0.21)$ & $(0.29)$ & $(0.37)$ \\
Minority $\times$ Non- & & 0.25 & & 0.14 & & 0.79 \\
Public Arena & & $(0.41)$ & & $(0.35)$ & & $(0.49)$ \\
Second Chamber & $-1.07^{*}$ & $-1.12^{* *}$ & 0.18 & 0.16 & $-0.75^{*}$ & $-0.60^{*}$ \\
& $(0.46)$ & $(0.46)$ & $(0.24)$ & $(0.23)$ & $(0.30)$ & $(0.30)$ \\
CVP & 0.30 & 0.36 & -0.26 & -0.28 & 0.57 & 0.32 \\
& $(0.41)$ & $(0.44)$ & $(0.19)$ & $(0.21)$ & $(0.36)$ & $(0.35)$ \\
SP & 0.28 & 0.30 & -0.15 & -0.17 & $0.61+$ & $0.59+$ \\
SVP & $(0.46)$ & $(0.47)$ & $(0.23)$ & $(0.24)$ & $(0.33)$ & $(0.32)$ \\
& 0.61 & 0.61 & $-0.51^{*}$ & $-0.54^{*}$ & 0.55 & 0.54 \\
Greens & $(0.40)$ & $(0.41)$ & $(0.23)$ & $(0.23)$ & $(0.36)$ & $(0.33)$ \\
& 0.71 & 0.79 & -0.48 & -0.43 & -0.68 & -0.63 \\
& $(0.56)$ & $(0.58)$ & $(0.59)$ & $(0.59)$ & $(0.76)$ & $(0.78)$ \\
& & & & & &
\end{tabular}


Table 3. (Continued)

\begin{tabular}{|c|c|c|c|c|c|c|}
\hline EDU/EVP/LIB/LDU & $\begin{array}{r}-0.61 \\
(0.61)\end{array}$ & $\begin{array}{r}-0.50 \\
(0.64)\end{array}$ & $\begin{array}{r}-0.09 \\
(0.39)\end{array}$ & $\begin{array}{r}-0.04 \\
(0.39)\end{array}$ & $\begin{array}{c}0.61 \\
(0.45)\end{array}$ & $\begin{array}{c}0.38 \\
(0.46)\end{array}$ \\
\hline AP/LEGA & $\begin{array}{r}-0.21 \\
(0.68)\end{array}$ & $\begin{array}{r}-0.15 \\
(0.67)\end{array}$ & $\begin{array}{r}-1.64 \\
(1.24)\end{array}$ & $\begin{array}{r}-1.61 \\
(1.25)\end{array}$ & $\begin{array}{c}0.78 \\
(0.48)\end{array}$ & $\begin{array}{c}0.54 \\
(0.51)\end{array}$ \\
\hline $\begin{array}{l}\text { Committee } \\
\text { Spokesperson }\end{array}$ & $\begin{array}{r}-0.70 \\
(0.83)\end{array}$ & $\begin{array}{r}-0.65 \\
(0.83)\end{array}$ & $\begin{array}{c}-0.79+ \\
(0.45)\end{array}$ & $\begin{array}{r}-0.77 \\
(0.50)\end{array}$ & $\begin{array}{c}0.47 \\
(0.34)\end{array}$ & $\begin{array}{c}0.50 \\
(0.38)\end{array}$ \\
\hline Chairperson & $\begin{array}{c}0.16 \\
(0.52)\end{array}$ & $\begin{array}{c}0.22 \\
(0.53)\end{array}$ & $\begin{array}{c}-1.40 * * \\
(0.44)\end{array}$ & $\begin{array}{c}-1.36 * * \\
(0.42)\end{array}$ & $\begin{array}{l}-2.54 * * \\
(0.51)\end{array}$ & $\begin{array}{c}-2.36 * * \\
(0.52)\end{array}$ \\
\hline Federal Councillor & $\begin{array}{r}-0.07 \\
(0.55)\end{array}$ & $\begin{array}{r}-0.01 \\
(0.54)\end{array}$ & $\begin{array}{c}-0.32 \\
(0.28)\end{array}$ & $\begin{array}{c}-0.21 \\
(0.30)\end{array}$ & $\begin{array}{c}-1.11 \\
(0.86)\end{array}$ & $\begin{array}{r}-1.11 \\
(0.88)\end{array}$ \\
\hline Age & $\begin{array}{c}0.00 \\
(0.02)\end{array}$ & $\begin{array}{c}0.01 \\
(0.02)\end{array}$ & $\begin{array}{r}-0.02 \\
(0.02)\end{array}$ & $\begin{array}{c}-0.03+ \\
(0.01)\end{array}$ & $\begin{array}{r}-0.01 \\
(0.02)\end{array}$ & $\begin{array}{r}-0.00 \\
(0.02)\end{array}$ \\
\hline Tenure & $\begin{array}{r}-0.01 \\
(0.02)\end{array}$ & $\begin{array}{r}-0.01 \\
(0.02)\end{array}$ & $\begin{array}{c}0.04 * \\
(0.02)\end{array}$ & $\begin{array}{l}0.04 * * \\
(0.02)\end{array}$ & $\begin{array}{r}-0.01 \\
(0.02)\end{array}$ & $\begin{array}{r}-0.01 \\
(0.02)\end{array}$ \\
\hline Gender & $\begin{array}{c}-0.93 * \\
(0.42)\end{array}$ & $\begin{array}{r}-1.02 * \\
(0.42)\end{array}$ & $\begin{array}{r}-0.41 \\
(0.25)\end{array}$ & $\begin{array}{c}-0.42+ \\
(0.24)\end{array}$ & $\begin{array}{c}-1.00 * * \\
(0.34)\end{array}$ & $\begin{array}{c}-0.85 * * \\
(0.32)\end{array}$ \\
\hline $\begin{array}{l}\text { Number of incoming } \\
\text { references }\end{array}$ & $\begin{array}{l}0.26 * * \\
(0.03)\end{array}$ & $\begin{array}{l}0.27^{* *} \\
(0.03)\end{array}$ & & & & \\
\hline $\begin{array}{l}\text { Number of outgoing } \\
\text { references }\end{array}$ & & & $\begin{array}{l}0.35 * * \\
(0.03)\end{array}$ & $\begin{array}{l}0.36 * * \\
(0.03)\end{array}$ & $\begin{array}{l}0.37 * * \\
(0.04)\end{array}$ & $\begin{array}{l}0.37 * * \\
(0.03)\end{array}$ \\
\hline Constant & $\begin{array}{r}-1.86^{*} \\
(1.00)\end{array}$ & $\begin{array}{c}-2.00+ \\
(1.04)\end{array}$ & $\begin{array}{r}-1.22 \\
(0.88)\end{array}$ & $\begin{array}{r}-0.93 \\
(0.85)\end{array}$ & $\begin{array}{r}-2.45 * \\
(1.15)\end{array}$ & $\begin{array}{c}-1.66 \\
(1.18)\end{array}$ \\
\hline Log-likelihood & -211.24 & -209.04 & -303.27 & -301.52 & -203.85 & -196.96 \\
\hline BIC & 544.65 & 559.54 & 728.70 & 744.49 & 529.87 & 535.37 \\
\hline$N$ & 620 & 620 & 620 & 620 & 620 & 620 \\
\hline Method & Poisson & Poisson & Poisson & Poisson & Poisson & Poisson \\
\hline
\end{tabular}

Notes: Estimated standard errors (clustered at the level of debate sequences) are shown in parentheses.

$* * P<0.01, * P<0.05,+P<0.10$.

status and issue type are positive and significant, implying that minority actors do more same-group referencing in the two linguistic issues than in the labor law debate. One possible reason for this is that in both linguistic debates there was also serious disagreement within the minority groups, which may have been conducive to more same-group referencing. With regard to the index of 'outgoing references from same group', our deliberative approach has a special focus on the behavior of the German-speaking majority. Therefore, we consider the interaction terms between majority status and issue types (rather than minority status and issue type). Model $9 \mathrm{~b}$ shows that the interaction terms between majority and issue types are negative and significant for outgoing references. This means that in the linguistic debates, the German-speaking majority made more references to minorities than in the labor law debate. This result is in line with our conception of the burden of reciprocity: majorities are expected to make special efforts to reach out to structural minorities when the latter's vital interests are concerned. A similar pattern can be observed for positive outgoing references of same group 
Table 4. Measures of reciprocity cont.

\begin{tabular}{|c|c|c|c|c|}
\hline & $\begin{array}{l}\text { Model 7a } \\
\text { Incoming } \\
\text { references } \\
\text { from same } \\
\text { group (index) }\end{array}$ & $\begin{array}{l}\text { Model } 7 \mathrm{~b} \\
\text { Incoming } \\
\text { references } \\
\text { from same } \\
\text { group (index) }\end{array}$ & $\begin{array}{c}\text { Model 8a } \\
\text { Positive } \\
\text { incoming } \\
\text { references from } \\
\text { same group (index) }\end{array}$ & $\begin{array}{l}\text { Model } 8 \mathrm{~b} \\
\text { Positive } \\
\text { incoming } \\
\text { references from } \\
\text { same group (index }\end{array}$ \\
\hline Minority Speakers & $\begin{array}{r}-0.09 \\
(0.22)\end{array}$ & $\begin{array}{r}-0.63 \\
(0.40)\end{array}$ & $\begin{array}{r}-0.81 * \\
(0.41)\end{array}$ & $\begin{array}{l}-1.75^{* *} \\
(0.43)\end{array}$ \\
\hline Language Article & $\begin{array}{c}0.30 \\
(0.22)\end{array}$ & $\begin{array}{c}-0.36 \\
(0.37)\end{array}$ & $\begin{array}{c}0.01 \\
(0.38)\end{array}$ & $\begin{array}{c}-0.34 \\
(0.47)\end{array}$ \\
\hline Language Law & $\begin{array}{c}0.07 \\
(0.18)\end{array}$ & $\begin{array}{c}-0.54+ \\
(0.32)\end{array}$ & $\begin{array}{c}0.22 \\
(0.38)\end{array}$ & $\begin{array}{r}-0.87^{*} \\
(0.39)\end{array}$ \\
\hline $\begin{array}{l}\text { Minority } \times \text { Language } \\
\text { Article }\end{array}$ & & $\begin{array}{l}1.55^{* *} \\
(0.53)\end{array}$ & & $\begin{array}{c}0.66 \\
(0.64)\end{array}$ \\
\hline $\begin{array}{l}\text { Minority } \times \text { Language } \\
\text { Bill }\end{array}$ & & $\begin{array}{l}1.50^{* *} \\
(0.46)\end{array}$ & & $\begin{array}{l}2.18^{* *} \\
(0.51)\end{array}$ \\
\hline Non-Public Arena & $\begin{array}{r}-0.09 \\
(0.15)\end{array}$ & $\begin{array}{c}0.38 \\
(0.27)\end{array}$ & $\begin{array}{c}0.12 \\
(0.26)\end{array}$ & $\begin{array}{c}0.34 \\
(0.43)\end{array}$ \\
\hline $\begin{array}{l}\text { Minority } \times \text { Non-Public } \\
\text { Arena }\end{array}$ & & $\begin{array}{r}-1.06^{*} \\
(0.42)\end{array}$ & & $\begin{array}{r}-0.44 \\
(0.52)\end{array}$ \\
\hline Second Chamber & $\begin{array}{r}-0.13 \\
(0.15)\end{array}$ & $\begin{array}{c}-0.12 \\
(0.15)\end{array}$ & $\begin{array}{r}-0.38 \\
(0.33)\end{array}$ & $\begin{array}{c}-0.38 \\
(0.24)\end{array}$ \\
\hline CVP & $\begin{array}{c}0.15 \\
(0.19)\end{array}$ & $\begin{array}{c}0.07 \\
(0.20)\end{array}$ & $\begin{array}{c}-0.15 \\
(0.29)\end{array}$ & $\begin{array}{r}-0.29 \\
(0.32)\end{array}$ \\
\hline SP & $\begin{array}{c}0.17 \\
(0.22)\end{array}$ & $\begin{array}{c}0.18 \\
(0.21)\end{array}$ & $\begin{array}{c}0.01 \\
(0.41)\end{array}$ & $\begin{array}{c}0.16 \\
(0.32)\end{array}$ \\
\hline SVP & $\begin{array}{c}0.28 \\
(0.26)\end{array}$ & $\begin{array}{c}0.31 \\
(0.24)\end{array}$ & $\begin{array}{c}-0.63 \\
(0.60)\end{array}$ & $\begin{array}{c}-0.48 \\
(0.61)\end{array}$ \\
\hline Greens & $\begin{array}{c}0.25 \\
(0.45)\end{array}$ & $\begin{array}{c}0.26 \\
(0.50)\end{array}$ & $\begin{array}{c}-0.81 \\
(1.22)\end{array}$ & $\begin{array}{c}-1.29 \\
(1.08)\end{array}$ \\
\hline EDU/EVP/LIB/LDU & $\begin{array}{c}0.11 \\
(0.32)\end{array}$ & $\begin{array}{c}0.19 \\
(0.33)\end{array}$ & $\begin{array}{c}0.39 \\
(0.35)\end{array}$ & $\begin{array}{c}0.19 \\
(0.31)\end{array}$ \\
\hline AP/LEGA & $\begin{array}{c}-0.08 \\
(0.53)\end{array}$ & $\begin{array}{r}-0.29 \\
(0.43)\end{array}$ & $\begin{array}{c}-1.05 \\
(1.05)\end{array}$ & $\begin{array}{c}-1.77+ \\
(1.08)\end{array}$ \\
\hline $\begin{array}{l}\text { Committee } \\
\text { Spokesperson }\end{array}$ & $\begin{array}{r}-0.07 \\
(0.42)\end{array}$ & $\begin{array}{r}-0.03 \\
(0.39)\end{array}$ & $\begin{array}{r}-0.43 \\
(0.84)\end{array}$ & $\begin{array}{l}0.00 \\
(0.77)\end{array}$ \\
\hline Chairperson & $\begin{array}{c}-0.22 \\
(0.28)\end{array}$ & $\begin{array}{c}-0.26 \\
(0.28)\end{array}$ & $\begin{array}{l}0.40 \\
(0.74)\end{array}$ & $\begin{array}{l}0.25 \\
(0.49)\end{array}$ \\
\hline Federal Councillor & $\begin{array}{c}0.05 \\
(0.35)\end{array}$ & $\begin{array}{c}0.10 \\
(0.32)\end{array}$ & $\begin{array}{r}-0.17 \\
(0.32)\end{array}$ & $\begin{array}{c}-0.10 \\
(0.38)\end{array}$ \\
\hline Age & $\begin{array}{c}0.00 \\
(0.01)\end{array}$ & $\begin{array}{c}-0.01 \\
(0.01)\end{array}$ & $\begin{array}{c}-0.01 \\
(0.02)\end{array}$ & $\begin{array}{c}-0.01 \\
(0.02)\end{array}$ \\
\hline Tenure & $\begin{array}{c}0.00 \\
(0.01)\end{array}$ & $\begin{array}{r}-0.00 \\
(0.01)\end{array}$ & $\begin{array}{c}-0.01 \\
(0.04)\end{array}$ & $\begin{array}{c}-0.02 \\
(0.04)\end{array}$ \\
\hline Gender & $\begin{array}{c}-0.35+ \\
(0.18)\end{array}$ & $\begin{array}{r}-0.34 * \\
(0.17)\end{array}$ & $\begin{array}{c}0.00 \\
(0.40)\end{array}$ & $\begin{array}{c}0.08 \\
(0.38)\end{array}$ \\
\hline $\begin{array}{l}\text { Number of Incoming } \\
\text { References }\end{array}$ & $\begin{array}{l}0.11^{* * *} \\
(0.02)\end{array}$ & $\begin{array}{l}0.10^{* *} \\
(0.02)\end{array}$ & & \\
\hline $\begin{array}{l}\text { Number of Positive } \\
\text { Incoming References }\end{array}$ & & & $\begin{array}{l}0.18+ \\
(0.11)\end{array}$ & $\begin{array}{c}0.15 \\
(0.09)\end{array}$ \\
\hline
\end{tabular}


Table 4. (Continued)

\begin{tabular}{lcccc}
\hline \hline Constant & -0.45 & -0.03 & -0.04 & 0.66 \\
& $(0.71)$ & $(0.70)$ & $(1.03)$ & $(1.08)$ \\
Phi & $0.35^{* *}$ & $0.37 * *$ & $0.26^{* *}$ & $0.29 * *$ \\
& $(0.01)$ & $(0.02)$ & $(0.02)$ & $(0.02)$ \\
Log-likelihood & 1356.05 & 1369.98 & 760.56 & 765.83 \\
BIC & -2592.02 & -2601.87 & -1427.29 & -1423.77 \\
$N$ & 405 & 405 & 109 & 109 \\
Method & Beta & Beta & Beta & Beta \\
\hline \hline
\end{tabular}

Notes: Estimated standard errors (clustered at the level of debate sequences) are shown in parentheses.

$* P<0.01, * P<0.05,+P<0.10$.

Table 5. Measures of Reciprocity cont.

\begin{tabular}{|c|c|c|c|c|}
\hline & $\begin{array}{l}\text { Model 9a } \\
\text { Outgoing } \\
\text { references to } \\
\text { same group } \\
\text { (index) }\end{array}$ & $\begin{array}{l}\text { Model 9b } \\
\text { Outgoing } \\
\text { references to } \\
\text { same group } \\
\text { (index) }\end{array}$ & $\begin{array}{l}\text { Model 10a } \\
\text { Positive } \\
\text { outgoing } \\
\text { references to same } \\
\text { group (index) }\end{array}$ & $\begin{array}{l}\text { Model 10b } \\
\text { Positive } \\
\text { outgoing } \\
\text { references to same } \\
\text { group (index) }{ }^{1}\end{array}$ \\
\hline Majority Speakers & $\begin{array}{c}-0.01 \\
(0.22)\end{array}$ & $\begin{array}{c}0.93^{*} \\
(0.39)\end{array}$ & $\begin{array}{c}-0.04 \\
(0.33)\end{array}$ & $\begin{array}{c}1.10 \\
(0.85)\end{array}$ \\
\hline Language Article & $\begin{array}{c}-0.15 \\
(0.20)\end{array}$ & $\begin{array}{l}0.56+ \\
(0.32)\end{array}$ & $\begin{array}{c}0.11 \\
(0.43)\end{array}$ & $\begin{array}{c}0.87 \\
(0.69)\end{array}$ \\
\hline Language Law & $\begin{array}{r}-0.31^{*} \\
(0.14)\end{array}$ & $\begin{array}{c}0.64^{*} \\
(0.26)\end{array}$ & $\begin{array}{c}0.08 \\
(0.40)\end{array}$ & $\begin{array}{l}1.03+ \\
(0.57)\end{array}$ \\
\hline $\begin{array}{l}\text { Majority } \times \text { Language } \\
\text { Article }\end{array}$ & & $\begin{array}{r}-1.10^{*} \\
(0.45)\end{array}$ & & $\begin{array}{c}-1.17 \\
(0.93)\end{array}$ \\
\hline $\begin{array}{l}\text { Majority } \times \text { Language } \\
\text { Bill }\end{array}$ & & $\begin{array}{l}-1.52^{* *} \\
(0.44)\end{array}$ & & $\begin{array}{c}-1.72+ \\
(0.89)\end{array}$ \\
\hline Non-Public Arena & $\begin{array}{r}-0.20 * \\
(0.10)\end{array}$ & $\begin{array}{c}-0.34+ \\
(0.21)\end{array}$ & $\begin{array}{c}0.08 \\
(0.24)\end{array}$ & $\begin{array}{c}0.30 \\
(0.54)\end{array}$ \\
\hline $\begin{array}{l}\text { Majority } \times \text { Non-Public } \\
\text { Arena }\end{array}$ & & $\begin{array}{c}0.30 \\
(0.36)\end{array}$ & & $\begin{array}{c}0.04 \\
(0.71)\end{array}$ \\
\hline Second Chamber & $\begin{array}{l}-0.42 * * \\
(0.15)\end{array}$ & $\begin{array}{l}-0.40^{* *} \\
(0.15)\end{array}$ & $\begin{array}{c}-0.49 \\
(0.33)\end{array}$ & $\begin{array}{c}-0.35 \\
(0.34)\end{array}$ \\
\hline CVP & $\begin{array}{c}-0.05 \\
(0.23)\end{array}$ & $\begin{array}{c}-0.18 \\
(0.24)\end{array}$ & $\begin{array}{l}0.06 \\
(0.32)\end{array}$ & $\begin{array}{c}-0.13 \\
(0.37)\end{array}$ \\
\hline SP & $\begin{array}{c}-0.16 \\
(0.21)\end{array}$ & $\begin{array}{c}-0.25 \\
(0.20)\end{array}$ & $\begin{array}{l}0.18 \\
(0.33)\end{array}$ & $\begin{array}{l}0.18 \\
(0.33)\end{array}$ \\
\hline SVP & $\begin{array}{c}-0.12 \\
(0.29)\end{array}$ & $\begin{array}{c}-0.17 \\
(0.28)\end{array}$ & $\begin{array}{c}0.49 \\
(0.39)\end{array}$ & $\begin{array}{l}0.54+ \\
(0.30)\end{array}$ \\
\hline Greens & $\begin{array}{c}0.01 \\
(0.33)\end{array}$ & $\begin{array}{c}-0.05 \\
(0.33)\end{array}$ & & \\
\hline EDU/EVP/LIB/LDU & $\begin{array}{c}-0.03 \\
(0.28)\end{array}$ & $\begin{array}{c}-0.03 \\
(0.29)\end{array}$ & $\begin{array}{c}-0.27 \\
(0.30)\end{array}$ & $\begin{array}{c}-0.50 \\
(0.32)\end{array}$ \\
\hline AP/LEGA & $\begin{array}{c}0.57 \\
(0.37)\end{array}$ & $\begin{array}{c}0.39 \\
(0.39)\end{array}$ & & \\
\hline
\end{tabular}


Table 5. (Continued)

\begin{tabular}{|c|c|c|c|c|}
\hline & $\begin{array}{l}\text { Model 9a } \\
\text { Outgoing } \\
\text { references to } \\
\text { same group } \\
\text { (index) }\end{array}$ & $\begin{array}{l}\text { Model 9b } \\
\text { Outgoing } \\
\text { references to } \\
\text { same group } \\
\text { (index) }\end{array}$ & $\begin{array}{l}\text { Model 10a } \\
\text { Positive } \\
\text { outgoing } \\
\text { references to same } \\
\text { group (index) }^{1}\end{array}$ & $\begin{array}{l}\text { Model 10b } \\
\text { Positive } \\
\text { outgoing } \\
\text { references to same } \\
\text { group (index) }{ }^{1}\end{array}$ \\
\hline $\begin{array}{l}\text { Committee } \\
\text { Spokesperson }\end{array}$ & $\begin{array}{c}0.05 \\
(0.34)\end{array}$ & $\begin{array}{c}0.10 \\
(0.31)\end{array}$ & $\begin{array}{c}0.64 \\
(0.61)\end{array}$ & $\begin{array}{c}0.86 \\
(0.54)\end{array}$ \\
\hline Chairperson & $\begin{array}{c}-0.43+ \\
(0.23)\end{array}$ & $\begin{array}{r}-0.47^{*} \\
(0.24)\end{array}$ & $\begin{array}{c}0.31 \\
(0.41)\end{array}$ & $\begin{array}{c}0.24 \\
(0.50)\end{array}$ \\
\hline Federal Councillor & $\begin{array}{l}-0.15 \\
(0.29)\end{array}$ & $\begin{array}{c}-0.05 \\
(0.28)\end{array}$ & $\begin{array}{c}-0.55 \\
(0.36)\end{array}$ & $\begin{array}{c}-0.55 \\
(0.42)\end{array}$ \\
\hline Age & $\begin{array}{c}0.01 \\
(0.01)\end{array}$ & $\begin{array}{c}0.00 \\
(0.01)\end{array}$ & $\begin{array}{c}-0.01 \\
(0.02)\end{array}$ & $\begin{array}{c}-0.00 \\
(0.02)\end{array}$ \\
\hline Tenure & $\begin{array}{r}-0.03^{*} \\
(0.01)\end{array}$ & $\begin{array}{r}-0.03^{*} \\
(0.01)\end{array}$ & $\begin{array}{c}0.02 \\
(0.02)\end{array}$ & $\begin{array}{l}0.00 \\
(0.02)\end{array}$ \\
\hline Gender & $\begin{array}{r}-0.03 \\
(0.22)\end{array}$ & $\begin{array}{c}0.03 \\
(0.22)\end{array}$ & $\begin{array}{c}0.11 \\
(0.45)\end{array}$ & $\begin{array}{c}0.10 \\
(0.44)\end{array}$ \\
\hline $\begin{array}{l}\text { Number of Outgoing } \\
\text { References }\end{array}$ & $\begin{array}{l}0.16^{* *} \\
(0.03)\end{array}$ & $\begin{array}{l}0.16 * * \\
(0.03)\end{array}$ & & \\
\hline $\begin{array}{l}\text { Number of positive } \\
\text { Outgoing References }\end{array}$ & & & $\begin{array}{l}0.57^{* *} \\
(0.11)\end{array}$ & $\begin{array}{l}0.59 * * \\
(0.11)\end{array}$ \\
\hline Constant & $\begin{array}{c}-0.52 \\
(0.72)\end{array}$ & $\begin{array}{c}-0.91 \\
(0.61)\end{array}$ & $\begin{array}{c}-1.24 \\
(0.99)\end{array}$ & $\begin{array}{c}-2.39+ \\
(1.36)\end{array}$ \\
\hline Phi & $\begin{array}{l}0.34^{* * *} \\
(0.01)\end{array}$ & $\begin{array}{l}0.36^{* *} \\
(0.02)\end{array}$ & $\begin{array}{l}0.27^{* *} \\
(0.02)\end{array}$ & $\begin{array}{l}0.28 * * \\
(0.01)\end{array}$ \\
\hline Log-likelihood & 1580.08 & 1587.80 & 881.66 & 884.27 \\
\hline $\mathrm{BIC}$ & -3040.94 & -3038.49 & -1679.22 & -1670.40 \\
\hline$N$ & 388 & 388 & 107 & 107 \\
\hline Method & Beta & Beta & Beta & Beta \\
\hline
\end{tabular}

Notes: Estimated standard errors (clustered at the level of debate sequences) are shown in parentheses.

$* P P<0.01, * P<0.05,+P<0.10$.

${ }^{1}$ Greens as well as AP/LEGA are perfectly predicted.

(model 10b, although the effect is only marginally significant). Notice, however, that linguistic minorities are far from being disrespectful toward majority speakers: in absolute terms, linguistic minorities made 28 positive references toward the German-speaking majority (whereas majority speakers made 47 positive references toward minority speakers). This indicates the willingness of linguistic minorities to include majority demands and arguments as well. With regard to negative incoming and outgoing references, the small number of observations (especially in the range between 0 and 1) makes it difficult to estimate robust models. Therefore, we do not report any findings.

Finally, for our index of 'incoming references from same group' (model 7b), there is also a negative and significant interaction effect between non-public arena 
and linguistic minorities. This implies that there is more cross-group referencing in the committee debates than in the plenary sessions. Given the fact that consequential decisions are generally crafted in the non-public committees, this is good news for the deliberative inclusion of linguistic minorities.

In sum, we think that these results for reciprocity are remarkable. Focusing on the extent of deliberative inclusion, the reciprocity levels between minority and majority actors differ little, and levels of respect are also similar; if they differ, then this is always tilted in favor of linguistic minorities. What stands out, however, are the interactive effects between minority/majority status and different types of issues. While there is a tendency of minorities to refer more to their own groups in the context of linguistic policies, the German-speaking majority simultaneously makes an explicit effort to refer more frequently to linguistic minorities under such conditions. Of course, our findings are based on a limited number of cases. To what extent we can generalize from our analysis remains open. However, we would still argue that our findings provide important first hints of how the deliberative inclusion of linguistic minorities works in the Swiss parliament (e.g. Bächtiger and Hangartner, 2010).

As for control variables, most control variables play no major role in shaping reciprocity levels. However, we detect an interesting discriminatory effect for women: when it comes to the frequency of incoming references, women get less incoming references than men (see Table 2). Moreover, there are some statistically significant effects for second chamber, chairpersons, Federal Councillors, and experience whereas partisan affiliation barely affects participation and reciprocity levels. These results are in line with previous findings on parliamentary deliberation, thus providing a validity check for the results obtained for the deliberative inclusion of linguistic minorities.

\section{Conclusion}

The study of minority inclusion is taking a deliberative turn. Even though most scholars still cling to institutional devices (such as formal representation or veto institutions) to include minorities and the disadvantaged in policy-making processes, it is unclear whether such 'external' inclusion also leads to 'internal' inclusion, that is, that minority demands are considered and are taken up by majorities (see Young, 2002). Deliberative approaches centering on reciprocity may fill this gap. Yet, deliberative approaches to minority inclusion have their own pitfalls. They may not adequately take into account the fact that majorities have the force of numbers on their side, potentially undermining the deliberative ideal of symmetric dialogue. Moreover, requiring the selflessness and self-transformation of the disadvantaged is not fair. In this paper, we have presented a deliberative model of 'internal' inclusion, focusing on reciprocity and respect in interactions between minorities and majorities. Reciprocity and respect are key components of the deliberative model (Gutmann and Thompson, 1996). Extending the work of Gutmann 
and Thompson, however, our focus on reciprocity and respect comes with a 'friendly amendment': we have put the 'burden of reciprocity' mainly on majorities and privileged groups. It is mainly their obligation to listen seriously and respond to the demands and arguments of minorities and the disadvantaged and show a willingness to respect and accommodate these interests. At the same time, this relaxation is conditional and partial. The less inequality minorities have experienced and the less their vital interests are at stake, the more we expect them to converge to the standards of majorities and privileged groups. Moreover, structural minorities and disadvantaged groups are also expected to make 'just' demands that do not compromize the basic well-being of majorities. Empirically, we applied our model to the interaction of linguistic groups in the Swiss parliament. We took a detailed look at reciprocity (interactivity and respect) in three decision cases, where two concerned the vital interests of linguistic minorities (linguistic article and linguistic bill) while one did not (labor law revision).

From the perspective of our deliberative approach, our findings are indicative of a highly egalitarian, sometimes even minority-favoring mode of interaction between the German-speaking majority and linguistic minorities. For reciprocity, our analysis generally documents a non-discriminatory pattern of referencing. Our in-depth analysis reveals that the German-speaking majority makes an effort to reach out more frequently to minorities under such conditions. In other words, the German-speaking majority is willing to shoulder the 'burden of reciprocity' when linguistic minorities' vital interests are concerned. The results also show that the majority listened carefully to arguments from linguistic minorities and referred to them in a highly respectful fashion. At the same time, linguistic minorities are slightly more self-referential and adversarial under such conditions. But from the perspective of our modified deliberative approach, it is legitimate for minorities to be less responsive to majorities and do politics in a slightly more adversarial and passionate way when their vital interests are affected. Yet we should not overlook the fact that linguistic minorities also made numerous of respectful utterances toward majorities. As such, linguistic minorities also fulfilled the obligation of being 'just' toward majorities, that is, retaining a modicum of respect toward majorities' demands and arguments.

Of course, the substantial degree of deliberative inclusion we found for linguistic minorities in Switzerland mirrors the country's fairly ideal setting for deliberative action. On the one hand, the Swiss political system involves a nonparliamentary consensus system and a party system, which is not organized along linguistic cleavages. This creates a flexible system of policy-making in which both the linguistic majority and the linguistic minorities are not (fully) bound by either partisan or group interests and can thus enter into relatively unconstrained deliberative interaction. On the other hand, this favorable institutional architecture is supported by appropriate motivations: many elite actors - and in particular German speakers - have identity-based preferences for the preservation of a multicultural Switzerland (Bächtiger and Steiner, 2004). This latter aspect 
may indeed be a crucial factor for minority inclusion (or, exclusion). As Vatter and Danaci (2010) find in an empirical analysis of direct-democratic votes that concerned minority rights in Switzerland, minorities have no difficulty realizing their interests as soon as they are viewed as a legitimate minority. Conversely, if minority groups are not viewed as legitimate minorities, majorities are far less willing to take minority interests into account. As such, our deliberative approach to inclusion may be highly dependent on appropriate actor motivations and appropriate perceptions of minorities and disadvantaged groups. While the Swiss consensus system creates incentives to be inclusive, the respectful 'acting' of the German-speaking majority toward linguistic minorities cannot be fully attributed to institutional incentives and necessities. Respect toward minority demands, for instance, is surely favored by specific institutional settings, but can hardly be prescribed by them. In the ongoing debate on the deliberative contours and related conflict-solving capacities of consociational institutions (Steiner et al., 2004; O'Flynn, 2007; O'Flynn, 2010), both our model and the results from the Swiss case indicate that classic consociationalism with its stress on actor willingness for successful cleavage management may not be as outdated as some have speculated (see, e.g. Horowitz, 2002).

Our study only delineates a starting point for exploring the deliberative inclusion of minorities and disadvantaged groups. Future research not only needs to engage in systematic comparative analysis of deliberative inclusion, it must also systematically explore the connection between process and outcomes. To date, we have only scattered evidence on whether a desirable decision-making process also translates into more deliberatively desirable outcomes. So far, most of the existing evidence is positive (see, e.g. Spörndli, 2004), but we must be open to the possibility that pathways other than deliberation lead to democratically desirable outcomes. Finally, our analysis of deliberative inclusion should contain dynamic aspects as well. In particular, we need to develop a more dynamic conception of the burden of reciprocity. In this regard, one could formulate an additional proviso, namely that the more inclusive majorities and advantaged groups are toward minorities and disadvantaged groups in the discussion process, the more we expect the latter to act likewise over time. These limitations notwithstanding, our study carves out both normative standards and empirical strategies to capture the deliberative aspects of one of the central challenges in democratic theory, namely the inclusion of structural minorities and disadvantaged groups.

\section{Acknowledgements}

The authors would like to thank Ian O'Flynn, Jane Mansbridge, Michael Morrell, Michael Neblo, John Parkinson, Marlène Gerber and three anonymous reviewers for excellent comments on previous versions of this article. They thank Dominik Hangartner and B. Dan Wood for generous and excellent advice on methodological and statistical issues. They also thank the Swiss National Science Foundation for financial support (NCCR Democracy 'Challenges to Democracy in the 21st 
Century'). Previous versions of this article were presented at the 2010 annual conference of the American Political Science Association and the 2009 conference on Measuring Representation at the University of Bern, Switzerland.

\section{Supplementary materials}

For supplementary material referred to in this article, please visit http:// dx.doi.org/doi:10.1017/S1755773912000239

\section{References}

Adcock, R. and D. Collier (2001), 'Measurement validity: a shared standard for qualitative and quantitative research', American Political Science Review 95: 529-546.

Amy, D.J. (1997), Proportional Representation. The Case for a Better Election System, Northampton, MA, USA: Crescent Street Press.

Bächtiger, A. and J. Steiner (2004), 'Switzerland: territorial cleavage management as paragon and paradox', in U. Amoretti and N. Bermeo (eds), Federalism and Territorial Cleavages, Baltimore: Johns Hopkins University Press, pp. 27-54.

Bächtiger, A. and D. Hangartner (2010), 'When deliberative theory meets empirical political science: theoretical and methodological challenges in political deliberation', Political Studies 58(4): 609-629.

Bächtiger, A., S. Niemeyer, M. Neblo, M.R. Steenbergen and J. Steiner (2010a), 'Disentangling diversity in deliberative democracy: competing theories, their empirical blind-spots, and complementarities', Journal of Political Philosophy 18: 32-63.

Bächtiger, A., S. Pedrini and M. Ryser (2010b), 'Prozessanalyse politischer Entscheidungen: Deliberative Standards, Diskurstypen und Sequenzialisierung', in J. Behnke, T. Bräuninger and S. Shikano (eds), Jahrbuch für Handlungs- und Entscheidungstheorie. Band 6: Schwerpunkt Neuere Entwicklungen des Konzepts der Rationalität und ihre Anwendungen, Wiesbaden: VS Verlag für Sozialwissenschaften, pp. 193-226.

Bickford, S. (1996), The Dissonance of Democracy: Listening, Conflict, and Citizenship, Ithaca, NY, USA: Cornell University Press.

Ceschi, R. (1991), 'Un Ticino poco svizzero? L'epoca dei malintesi 1880-1940', Neue Studien zum Schweizerischen Nationalbewusstsein, Fasc. 13: 53-65., Basel: Schwabe.

Dobson, A. (2010), 'Democracy and nature: speaking and listening', Political Studies 58: 752-768.

Dryzek, J.S. and S. Niemeyer (2008), 'Discursive representation', American Political Science Review 102(4): 418-493.

Du Bois, P. (1999), Alémanniques et Romands entre unité et discorde, Lausanne: Favre.

Eidgenössische Volkszählung (2000), 'Sprachenlandschaft in der Schweiz.' Retrieved 28 September 2011 from http://www.bfs.admin.ch/bfs/portal/de/index/themen/01/22/publ.Document.52216.pdf.

Espinoza, J.A. and R.T. Garza (1985), 'Social group salience and interethnic cooperation', Journal of Experimental Social Psychology 21(4): 380-392.

Ferrari, S. and F. Cribari-Neto (2004), 'Beta regression for modelling rates and proportions', Journal of Applied Statistics 31(7): 799-815.

Gerber, M. (2012), 'On the possibility of fruitful dialogue among a collection of strangers. European Citizen Participation in a pan-European Deliberative Poll (Europolis).' Paper presented at the 'Conference on Deliberative Democracy in Action', 5-7 June 2012, Turku/Åbo.

Goodin, R.E. (2000), 'Democratic deliberation within', Philosophy and Public Affairs 29: 81-109.

Gutmann, A. and D. Thompson (1996), Democracy and Disagreement, Cambridge, MA, USA: Harvard University Press.

Horowitz, D.L. (2002), 'Constitutional design. Proposals versus processes', in A. Reynolds (ed.), The Architecture of Democracy. Constitutional Design, Conflict Management, and Democracy, Oxford: Oxford University Press, pp. 15-36. 
Knight, J. and J. Johnson (1997), 'What sort of equality does deliberative democracy require?', in J. Bohman and W. Rehg (eds), Deliberative Democracy, Cambridge, MA, USA: MIT Press, pp. 279-320.

Kübler, D., I. Papadopoulos and O. Mazzoleni (2009). 'Le plurilinguisme de la Confédération Représentation et pratiques linguistiques dans l'administration fédérale.' Retrieved 28 September 2011 from http://www.nfp56.ch/d_projekt.cfm?Projects.Command=details\&get=26\&kati=3.

Lazer, D., B. Rubineau, C. Chetkovitch, N. Katz and M. Neblo (2010), 'The coevolution of networks and political attitudes', Political Communication 27: 248-274.

Levitt, S. (2004), 'Testing theories of discrimination: evidence from weakest link', Journal of Law and Economics 47: 431-452.

Lijphart, A. (1977), Patterns of Democracy: Government Forms and Performance in Thirty-Six Countries, New Haven: Yale University Press.

Linder, W. (2005), Schweizerische Demokratie. Institutionen, Prozesse, Perspektiven, Bern: Haupt.

Long, J.S. (1997), Regression Models for Categorical and Limited Dependent Variables, Thousand Oaks: Sage.

Markovits, E. (2006), 'The trouble with being earnest: deliberative democracy and the sincerity norm', Journal of Political Philosophy 14: 249-269.

Mansbridge, J., J. Bohman, S. Chambers, T. Christiano, A. Fung, J. Parkinson, D. Thompson and M Warren (2012), 'A Systemic Approach to Deliberative Democracy', in J. Parkinson and J. Mansbridge (eds), Deliberative Systems: Deliberative Democracy at the Large Scale, Cambridge: Cambridge University Press, pp. 1-26.

Mendelberg, T. and C. Karpowitz (2007), 'How people deliberate about justice: groups, gender, and decision rules', in S.W. Rosenberg (ed.), Deliberation, Participation and Democracy: Can the People Govern?, London: Palgrave Macmillan, pp. 101-129.

Mutz, D.C. (2008), 'Is deliberative democracy a falsifiable theory?', Annual Review of Political Science 11: $521-538$.

O’Flynn, I. (2007), 'Divided societies and deliberative democracy', British Journal of Political Science 37(4): 731-751.

- (2010), 'Deliberative democracy, the public interest and the consociational model', Political Studies 58(3): 572-589.

Philips, A. (1995), The Politics of Presence, Oxford, UK: Clarendon Press.

Sanders, L. (1997), 'Against deliberation', Political Theory 25: 347-375.

Schmid, C.L. (1981), Conflict and Consensus in Switzerland, Berkeley and Los Angeles: University of California Press.

Schneiderhan, E. and S. Khan (2008), 'Reasons and inclusion: the foundation of deliberation', Sociological Theory 26: 1-24.

Spörndli, M. (2004), Diskurs und Entscheidung. Eine empirische Analyse kommunikativen Handelns im deutschen Vermittlungsausschuss, Wiesbaden: VS Verlag für Sozialwissenschaften.

Stasavage, D. (2007), 'Polarization and publicity: rethinking the benefits of deliberative democracy', Journal of Politics 69: 59-72.

Steenbergen, M.R., A. Bächtiger, M. Spörndli and J. Steiner (2003), 'Measuring political deliberation: a discourse quality index', Comparative European Politics 1: 21-48.

Steiner, J., A. Bächtiger, M. Spörndli and M.R. Steenbergen (2004), Deliberative Politics in Action. Analysing Parliamentary Discourse, Cambridge: Cambridge University Press.

Thompson, D. (2008), 'Deliberative democratic theory and empirical political science', Annual Review of Political Science 11: 497-520.

Urbinati, N. (2000), 'Representation as advocacy: a study of democratic deliberation', Political Theory 28: $758-786$.

Valadez, J.M. (2001), Deliberative Democracy, Political Legitimacy, and Self-Determination in Multicultural Societies, Boulder, Colo.: Westview Press.

Vatter, A. and D. Danaci (2010), 'Mehrheitstyrannei durch volksentscheide? zum spannungsverhältnis zwischen direkter demokratie und minderheitenschutz', Politische Vierteljahresschrift 51(2): 205-222. 
Warren, M.E. (2006), 'What should and should not be said: deliberating sensitive issues', Journal of Social Philosophy 37: 163-181.

Williams, M.S. (1998), Voice, Trust and Memory: Marginalized Groups and the Failings of Liberal Representation, Princeton: Princeton University.

- (2000), 'The uneasy alliance of group representation and deliberative democracy', in W. Kymlicka and W. Norman (eds), Citizenship in Diverse Societies, Oxford: Oxford University Press, pp. $124-152$.

Young, I.M. (2001), 'Activist challenges to deliberative democracy', Political Theory 29: 670-690.

— (2002), Inclusion and Democracy, Oxford: Oxford University Press. 